\title{
The business perspective on materials criticality: evidence from manufacturers
}

\author{
YuliaLapko a,b, PaoloTrucco a, CaliNuur b
}

a Politecnico di Milano, Department of Management, Economics and Industrial Engineering, Piazza Leonardo da Vinci32, 20133 Milan, Italy

b Department of Industrial Economics and Management, KTH Royal Institute of Technology, Lindstedtsvägen 30,SE-11428 Stockholm, Sweden

\section{Highlights:}

- There are interdependences between manufacturers using the same critical materials for different applications

- Materials criticality transforms the supply chain

- Manufacturers employ limited portfolios of mitigation strategies

- Governance interventions might be required for strategies seen as irrelevant or challenging at the company level

\begin{abstract}
The European Commission identified a group of materials that were claimed to be critical due to their high economic importance and high supply constraints, which could become bottlenecks for the deployment of emerging technologies and enabling sustainable production. Currently this discourse takes place at the industrial system level from a policy perspective, and it is unclear if what is perceived by policy circles as critical could be true for manufacturing operations. This paper explores how five EU manufacturing companies in different sectors and supply chains see materials criticality, and their strategies to mitigate such criticality. On the one hand, the results indicate the limited scope of the criticality factors and employed mitigation strategies considered, compared to those established in the literature. On the other hand, the findings point to the existence of interdependences between companies within and between supply chains, which should be incorporated into the materials criticality assessment, if viable implications for the industrial systems are to be developed. The paper concludes by discussing the implications for manufacturing companies and policy-makers, and suggests prospects for further research.
\end{abstract}

Key words: critical materials, manufacturers, criticality factors, mitigation strategies. 


\section{Introduction}

Availability of resources has always been a core requirement for the development of nations and economic growth. Historically, the exploration of new areas, population migration and wars have been driven by the need to extend the resource base and ensure its accessibility. Resources have retained their important position, although nowadays the context has changed in various ways. This is a consequence of the exponential increase in the world population and economic growth that drives the consumption of energy and material resources and creates great pressure on their supply (e.g. Krautkraemer, 2005). As Morley and Eatherley (2008) indicate, there are increasing concerns in old industrialised nations about the increasing price of materials and possible shortages of supply inhibiting profitability and volume growth, the increasing control of these resources by fewer organisations, and the allocation of resources in favour of domestic companies via export quotas. Sustainability issues such as sustainable extraction rates, the environmental regulation of mining, and land use competition, add constraints on the availability of materials.

Minerals are the resource of particular focus in this study. Generally, there are two views in the literature of the longterm availability of minerals, the fixed stock and the opportunity cost paradigms (Poulton et al., 2013; Tilton, 2003). According to the opportunity cost paradigm, in periods of mineral scarcity, technological progress would be enhanced by the increased price of minerals (Graedel et al., 2014; Gunn and Bloodworth, 2012), however, it is not always possible to include all costs in the price of minerals, as some costs might not be known when price is established, and future changes in the demand and supply base cannot be taken into consideration. As Bell et al. (2013) note, while innovation, discovery, and technological development might be reliable pillars for the mitigation of resource scarcity, there are doubts about whether technology alone is able to solve this. According to the fixed stock paradigm, the depletion of mineral resources is just a matter of time, as the earth is finite and, therefore, mineral supply is also finite (Tilton, 2003).

In recent decades, concerns over the availability of materials have changed from being about the availability of rather basic industrial raw materials such as zinc, lead, and nickel for meeting the demands of the defence industry (known as “strategic” materials), to specialised, low-volume metals (e.g. indium, germanium, rare earth elements) which enable the deployment of green energy technologies in various products (in solar panels, wind turbines, electric vehicles, for example) and modern consumer electronics (such as mobile phones, tablets, laptops). From a policy perspective, these 
are seen as "critical” materials (Buchert et al., 2009; European Commission, 2014a, 2010; Moss et al., 2011; U.S. Department of Energy, 2011).

The concept of materials criticality was born from the concern that some materials (in particular, metals and minerals) may become scarce and no longer routinely available for production and technology (Graedel et al., 2014). In a review of the descriptors of critical raw materials (CRM), Peck et al. (2015) argue that there are no broadly accepted definitions and that the research stream lacks coherence.

In general, materials criticality is characterised by a high probability of supply constraints and the high impact of supply destruction (Erdmann and Graedel, 2011; Graedel and Reck, 2015; Peck et al., 2015). Supply constraints can be caused by a myriad of factors such as physical interruptions (e.g. due to war), governance interventions (e.g. export bans), or market imbalances (e.g. inability to expand supply to meet demand increase, high market concentration) (Erdmann and Graedel, 2011). These supply constraints may lead to two major supply disruptions, a shortage of physical supply, and/or a price increase and volatility, making a material either unavailable or unaffordable (Buijs and Sievers, 2012).

Materials criticality discourse was born at the industrial system level from the policy perspective. Studies of materials criticality analysed materials flows in a scope of a country or region (e.g. European Commission, 2014; Panousi et al., 2015) or else the analysis was done for a particular set of technologies (e.g. Moss et al., 2011; U.S. Department of Energy, 2011), however, Buijs et al. (2012) suggest that studies disregard the risks related to the production chain and focus instead on the mining and export of raw materials.

From a manufacturing perspective, materials criticality, as a supply-demand mismatch, creates an uncertain business environment and threatens the continuity of production operations. Despite its importance and potential impact on business, to our knowledge, very few studies (Graedel et al., 2012; Mroueh et al., 2014; Rosenau-Tornow et al., 2009; Slowinski et al., 2013) have considered the manufacturer's perspective and incorporated implications for businesses when studying materials criticality issues. There is a lack of empirically grounded analysis on the risk factors related to the use of critical materials in the context of manufacturing firms, and on the strategies that manufacturers adopt to mitigate these risks.

The paper aims to address this gap and poses two main research questions: 
- $\quad$ RQ1 How do manufacturing companies view and mitigate materials criticality?

- RQ2 How do materials criticality factors and the mitigation strategies employed by companies relate to the factors and strategies established in the literature at the industrial system level?

Supply chain and supplier risks serve as the lenses of analysis in this paper. As the conceptualisation of materials criticality is still developing, these two lenses help in setting the conceptual grounds for an examination of materials criticality at the company level. Supply chain and supplier risk research streams investigate the risks that organisations face through the supply of materials and services, the buyer-supplier relationships, and how they mitigate these risks; we therefore argue that they are useful concepts to identify materials criticality factors from a business perspective. The two lenses of analysis differ in scope and aim to examine whether different companies view materials criticality differently (not only regarding a single factor, but also in the scope of their concern).

The research questions are addressed through exploratory case study research, which is based on a sample of five companies from different industries and from different positions in the supply chain. Building on the literature on supply chain risks, supplier risks and materials criticality, the risk factors related to the use of critical materials and adopted mitigation strategies in the context of manufacturing firms are identified. The findings have implications for the existing materials criticality factors established at the industrial system level, and for policy-makers developing (resources) policy actions in order to establish proper requirements and provide the required support.

After this introduction, the paper is structured as follows. Section 2 provides the theoretical background of materials criticality factors and mitigation strategies from the industrial system level, and supply chain and supplier risk factors and mitigation strategies are reviewed. The section ends with a description of the framework for analysis. Section 3 describes the study methodology. The paper presents (Section 4) and discusses (Section 5) the empirical findings from the five companies. The paper ends with conclusions and implications for business stakeholders and policy-makers, and provides suggestions for further research.

\section{Theoretical background}


This section is dedicated to materials criticality factors and mitigation strategies as discussed in the literature; and to supply chain and supplier risk factors and mitigation strategies. Finally,the framework of analysis is introduced.

\subsection{Materials criticality factors}

The analysis of materials criticality has been addressed using various approaches (Erdmann and Graedel, 2011; Graedel and Reck, 2015; Peck et al., 2015). For instance, the European Commission (2010) aggregates materials criticality factors into two dimensions, supply risk and economic importance, but Graedel et al. (2012) analyse materials criticality space with respect to three dimensions, supply risk, the vulnerability of supply restrictions and environmental implications.

Although the dimensions employed in different studies might seem to be alike, they are represented through an aggregation of different factors (Erdmann and Graedel, 2011; Graedel and Reck, 2015). Achzet and Helbig (2013) and Helbig et al. (2016) review factors for measuring supply risk and vulnerability, and both studies suggest a lack of consensus in the literature. Erdmann and Graedel (2011) describe how differently substitutability is addressed in various studies: under supply risks (European Commission, 2010), as a major constituent of vulnerability (NRC, 2008), and as both indicator for vulnerability and supply risk in the assessment methodology of General Electric (Slowinski et al., 2013). Graedel and Reck (2015) suggested that the inclusion of environmental and economic issues in criticality analysis in a generalised framework is rather problematic due to a measurement problem, its relevance to certain materials or to certain levels of analysis.

Materials criticality is a dynamic issue (Graedel et al. 2014) and subject to changes in society's view of certain raw materials, technological change and political vision (Erdmann and Graedel 2011). The scarcity of other resources required for production processes, such as energy and water, also has an impact on criticality determination (Henckens et al., 2014). The time horizons, organisational levels (e.g. company, industrial system, nation etc.) and particular applications of minerals considered impose limitations on criticality determination (Erdmann and Graedel 2011; Graedel et al. 2014; Graedel et al. 2012). Table 1 lists the criticality factors found in peer reviewed journal papers, policy reports and research project reports.

In extant literature only three studies offer materials criticality factors at the company level (Graedel et al., 2012; Nieto et al., 2013; Rosenau-Tornow et al., 2009), and they lack empirical validation. 


\subsection{Materials criticality mitigation strategies}

The literature has discussed a variety of actions to offset materials criticality. It tends to provide suggestions for criticality mitigation actions which are in line with the concepts of closing the loop and material efficiency, and calls for the involvement of all stakeholders (e.g. mining companies, manufacturing companies, recycling companies, governments), however, few papers provide a comprehensive framework of mitigation actions: Wäger et al. (2012) aggregate various approaches into a generic framework with categorisation according to life cycle phases (mining, manufacturing, product use, recycling); and Weiser et al. (2015), building on Wäger et al. (2012), differentiate between technology options (e.g. substitution and material efficiency) and governance interventions (e.g. taxation and legislation). Table 2 lists the mitigation strategies.

Insert Table 2 about here

Although providing the required input, the suggested strategies are somewhat isolated from each other and it could be argued that they do not provide a solid platform for decision-making processes. Both Wäger et al. (2012) and Weiser et al. (2015) suggest a need for balancing/aligning the application of different approaches and their prioritisation and managing trade-offs between applications.

Although the majority of publications discuss activities for offsetting materials criticality and provide suggestions (explicitly or implicitly) for manufacturing companies, only a few publications performed empirical studies to explore manufacturer’s perspective. Slowinski et al. (2013), Peck and Bakker (2012) and Mroueh et al. (2014) report on strategies that manufacturing companies from various industries employ to mitigate materials criticality, however, none of these studies performed a cross-company analysis, for example, for comparing strategies adopted by manufacturers located differently within the supply chain, or comparing differences between sectors and products.

\subsection{Supply chain risk categories}

Supply chain risks are risks that a supply chain imposes on a company. The scope of these risks includes multiple actors, particularly suppliers, supplier's suppliers, customers, and customer's customers. Table 3 lists categories of supply chain risks and presents examples of risk factors in each risk category. Eight risk categories were selected: Supply, Demand, 
Internal Operations, Information, Competition, Regulatory/Policy, Geopolitical, Sustainability. These risk categories are commonly used in the literature and relevant to material criticality factors. Other risk categories, such as transportation risks, infrastructure risks and disasters, were not included in the study. The financial risks category is not considered separately. Instead, we consider price as a part of supply risk, based on the findings of Fischl et al. (2014)'s literature review.

Insert Table 3 about here

\subsection{Supplier risk categories}

Supplier risks are the risks that a single supplier poses (under control of a supplier), plus the risks related to supplierbuyer relationships. Table 4 lists five supplier risk categories with examples of risk factors in each risk category. These are Business, Performance, Capabilities, Relationship and Sustainability. Although some authors include sustainability issues also under performance category, we choose to consider all sustainability related issues under a separate category.

Insert Table 4 about here

\subsection{Risk mitigation strategies}

Many different mitigation strategies have been suggested for supplier and supply chain risks. Zsidisin and Ellram (2003) divide strategies between behaviour-based management and buffer-oriented management; while Giunipero and Eltantawy (2004) differentiate between traditional risk buffering and risk management. Some researchers assign risk mitigation strategies for a precise risk category (e.g. Ho et al., 2015; Tang and Tomlin, 2008; Tang, 2006a, 2006b); while others distinguished risk strategies for specific risk factors (; ; Tang and Musa, 2011).

In this paper, the six risk mitigation strategies developed by Jüttner et al. (2003) and Manuj and Mentzer (2008) are used for analysis. These are:

- postponement - delaying the actual commitment of resources to maintain flexibility and delay incurring costs;

- $\quad$ speculation - forward placement of inventory in country markets, forward buying of finished goods or raw material inventory, and early commitment to the form of a product, all in anticipation of future demand;

- $\quad$ hedging - a globally dispersed portfolio of suppliers and facilities;

- control/share/transfer - vertical integration, contracts, and agreements; 
- $\quad$ security - supply chain visibility and security of the different flows;

- $\quad$ avoidance - auditing, termination of contracts.

Tang (2006a) argues that the implementation of mitigation strategies should be executed in a proactive manner, have a strategic fit and benefits should cover the costs. Ho et al. (2015) highlight the importance of meeting mitigation strategy with risk type and factors. From the perspective of this study, this means that investigation of the strategies implemented by manufacturers to deal with CRM issues may suggest how businesses really perceive and face the problem, if any.

\subsection{Development of the framework for analysis}

This sub-section consolidates the literature on materials criticality and supply chain and supplier risks to shape the framework for analysis. As the paper examines the risk factors that underpin materials criticality as perceived by companies and their mitigation strategies, two dimensions of analysis are chosen: risk/criticality factors and mitigation strategies. Risks associated with critical materials (by the case companies) will be analysed according to supply chain and supplier risks categories and the materials criticality factors indicated in the literature. Table 5 presents risk categories and the associated factors of materials criticality. The factors are assigned codes which are used in data analysis.

Insert Table 5 about here

Mitigation strategies employed by the case companies will be analysed according to the types of mitigation strategies suggested by Manuj and Mentzer (2008) and materials criticality mitigation strategies indicated in the literature (Table 6). The strategies are assigned codes which are used in data analysis.

Insert Table 6 about here

\section{Method}

Materials criticality has only recently attracted the attention of the academic community, and it is still in the conceptualising phase, where definitions and metrics are being developed. It is a complex and multidisciplinary phenomenon that affects various organisations within supply chains and among them. Given these characteristics, the exploratory qualitative case study research approach is argued to be beneficial (Eisenhardt and Graebner, 2007; Stuart 
et al., 2002; Yin, 2009). Indeed, the previous empirical studies that explore manufacturer perspectives on materials criticality (Mroueh et al., 2014; Peck and Bakker, 2012; Slowinski et al., 2013) adopted case based research designs, engaging with different business stakeholders through interviews and round tables. In this paper, an exploratory case study is chosen as the research design.

It should be noted that there is a tradition associating a "case” with an “organisation” (e.g. Yin, 2009), the present study favours the multi-cited ethnography as discussed by Burrell (2009), Green (1999), Nadai and Maeder (2005). This approach aims to explore a complex phenomenon that occurs at multiple sites, which represent an element of a puzzle, to provide answers to different questions, rather than serve only as means of comparisons for the same process, as for example in multiple case study research. This study uses the companies involved both as points of comparison for identifying the differences and commonalities that exist in relation to materials criticality factors and strategies, and the sites in order to collect information about what constitutes materials criticality and its mitigation.

Since the goal is to explore manufacturer perceptions and mitigation of materials criticality, the unit of analysis set for this study is a single organisation that uses critical materials for manufacturing components or final products.

\subsection{Selection of companies}

As discussed earlier, the present paper takes the perspective of companies manufacturing components and final products. Geographical scope is important for materials criticality determination, as different countries are subject to different supply risks, have different industrial structures, set different levels of importance for industrial sectors and different environmental legislation (European Commission, 2010; Peck et al., 2015). This study is therefore limited to the geographic scope of firms located in the European Union (EU). The European Commission (2014a) provided a recent list of critical materials, on which this study focuses in particular on metals: antimony, beryllium, cobalt, chromium, gallium, germanium, indium, magnesite, magnesium, niobium, platinum group metals, rare earth elements, and tungsten. An initial list of potential companies to approach was built, based on materials criticality reports at the European Union level, where the list of critical materials was presented and their applications were described (European Commission, 2014a; Mroueh et al., 2014).

Previous publications have indicated that the criticality determination and mitigation actions adopted by companies are subject to such factors as the supply chain position of a company (Mroueh et al., 2014), application of the material 
(Graedel et al., 2012), product lifetime and volumes of contained materials (Mroueh et al., 2014). Given the exploratory nature of the study, we aimed to ensure diversity among companies in respect to these factors. This information-oriented selection ensures that the chosen companies will provide the required data for the intended investigation (Eisenhardt, 1989; Flyvbjerg, 2006; Yin, 2009). The selection criteria are the following:

- manufacturing companies with different positions (roles) in the supply chain (or combining different roles),

- manufacturing companies that use different CRMs in various product applications, in order to take into consideration the potential influence of different CRM, products, and sectors,

- manufacturing companies that are located within the EU.

The final company selection was made by contacting companies via email and phone to verify their suitability and availability. The profiles of the companies involved in the study are presented in Table 7 and Figure 1.

Table 7. Profile of the companies.

\begin{tabular}{|l|l|l|l|l|l|}
\hline $\begin{array}{l}\text { Position in the } \\
\text { supply chain } \\
\text { used }\end{array}$ & $\begin{array}{l}\text { Examples of CRM } \\
\text { (component } \\
\text { and/or } \\
\text { product) }\end{array}$ & Sector & Interviewee & Secondary data \\
\hline $\begin{array}{l}\text { Materials and } \\
\text { components } \\
\text { manufacturer and } \\
\text { recycler (C1) }\end{array}$ & $\begin{array}{l}\text { Germanium, indium, } \\
\text { cobalt, platinum } \\
\text { group metals, etc. } \\
\text { applications }\end{array}$ & $\begin{array}{l}\text { Multiple } \\
\text { sectors }\end{array}$ & $\begin{array}{l}\text { Director of EU } \\
\text { Government } \\
\text { Affairs }\end{array}$ & $\begin{array}{l}\text { Annual Reports } \\
\text { 2015-2005; } \\
\text { p presentations; } \\
\text { Information on the } \\
\text { company's } \\
\text { webpage }\end{array}$ \\
\hline $\begin{array}{l}\text { Component } \\
\text { manufacturers }\end{array}$ & $\begin{array}{l}\text { Rare earth elements, } \\
\text { cobalt, platinum } \\
\text { group metals }\end{array}$ & $\begin{array}{l}\text { Multiple } \\
\text { applications }\end{array}$ & $\begin{array}{l}\text { Multiple } \\
\text { sectors }\end{array}$ & $\begin{array}{l}\text { Environmental } \\
\text { Chemistry } \\
\text { Office Manager, } \\
\text { Corporate }\end{array}$ & $\begin{array}{l}\text { Annual Reports } \\
\text { (Form 20-F) 2014- } \\
\text { 2009; } \\
\text { Quality and } \\
\text { Eresentation; } \\
\text { Information on the } \\
\text { company's } \\
\text { webpage }\end{array}$ \\
\hline $\begin{array}{l}\text { Components } \\
\text { manufacturer } \\
\text { (C3) }\end{array}$ & Niobium & $\begin{array}{l}\text { Superconduc } \\
\text { ting wires } \\
\text { and cables }\end{array}$ & $\begin{array}{l}\text { ICT and } \\
\text { electronics }\end{array}$ & $\begin{array}{l}\text { Vice President } \\
\text { and Plant } \\
\text { Manager, }\end{array}$ & $\begin{array}{l}\text { Information on the } \\
\text { company's } \\
\text { webpage }\end{array}$ \\
\hline $\begin{array}{l}\text { Final products } \\
\text { manufacturer } \\
\text { (C4) }\end{array}$ & $\begin{array}{l}\text { Gallium, indium, } \\
\text { germanium etc. }\end{array}$ & $\begin{array}{l}\text { IP-routing } \\
\text { solutions }\end{array}$ & $\begin{array}{l}\text { ICT and } \\
\text { electronics }\end{array}$ & $\begin{array}{l}\text { Supply chain } \\
\text { manager of a } \\
\text { global business } \\
\text { unit (radio } \\
\text { transmission } \\
\text { systems) } \\
\text { Material } \\
\text { procurement } \\
\text { manager (radio }\end{array}$ & $\begin{array}{l}\text { Annual reports } \\
\text { 2003-5; } \\
\text { Annual reports } \\
\text { (Form 20-F) 2006- } \\
\text { 2014; } \\
\text { Document de } \\
\text { Référence 2005; } \\
\text { infditional } \\
\text { information }\end{array}$ \\
\hline
\end{tabular}




\begin{tabular}{|l|l|l|l|l|l|}
\hline & & & & $\begin{array}{l}\text { transmission } \\
\text { systems) }\end{array}$ & $\begin{array}{l}\text { document 2008- } \\
\text { 2014; } \\
\text { CSR reports 2006- } \\
\text { 20012; } \\
\text { Information on the } \\
\text { company's } \\
\text { webpage }\end{array}$ \\
\hline $\begin{array}{l}\text { Final product } \\
\text { manufacturers } \\
\text { (C5) }\end{array}$ & $\begin{array}{l}\text { Rare earth elements, } \\
\text { platinum group } \\
\text { metals, etc. }\end{array}$ & $\begin{array}{l}\text { Heavy } \\
\text { vehicles }\end{array}$ & Automotive & $\begin{array}{l}\text { Section } \\
\text { Manager } \\
\text { Materials } \\
\text { Technology and } \\
\text { Standards }\end{array}$ & $\begin{array}{l}\text { Annual Report } \\
\text { 2015-2005; } \\
\text { Sustainability } \\
\text { report 2014; } \\
\text { Information on the } \\
\text { company's } \\
\text { webpage }\end{array}$ \\
\hline
\end{tabular}

\begin{tabular}{|c|c|c|c|c|}
\hline Automotive & \multicolumn{3}{|c|}{ C5 } & \\
\hline \multirow{2}{*}{$\begin{array}{c}\text { ICT and } \\
\text { electronics }\end{array}$} & \multicolumn{3}{|r|}{$\mathrm{C} 4$} & \\
\hline & \multicolumn{2}{|r|}{ C3 } & & \\
\hline \multirow{3}{*}{$\begin{array}{l}\text { Multiple } \\
\text { sectors }\end{array}$} & & $\mathrm{C} 2$ & & \\
\hline & \multicolumn{2}{|c|}{$\mathrm{C} 1$} & & C1 \\
\hline & $\begin{array}{c}\text { Material } \\
\text { manufacturer }\end{array}$ & $\begin{array}{l}\text { Component } \\
\text { manufacturer }\end{array}$ & $\begin{array}{l}\text { Final product } \\
\text { manufacturer }\end{array}$ & Recycler \\
\hline Sector & \multicolumn{4}{|c|}{ Supply chain position } \\
\hline
\end{tabular}

Figure 1. Companies in relation to sectors and supply chain position.

\subsection{Data collection}

The main sources of data collection were interviews with representatives of companies and the different reports available on the webpages of companies in order to enable triangulation of the data (Eisenhardt, 1989).

Interviews were conducted with the managers responsible for purchase and supply management and sustainability, and senior managers with an overall view of their business. Managers in these positions have responsibilities for issues relevant to materials criticality, and are therefore knowledgeable and able to provide valid information. The interviews had two objectives: to create the basis for comparison between companies through addressing the same issues, and also to obtain additional information about materials criticality from the perspective of a particular company, given its supply chain position. Semi-structured interviews were used to meet these goals. This type of interview allows for some flexibility in the conversation and does not set constraints on questions. This is important in exploratory research, because 
an interview can provide insights beyond the interview guide. On the other hand, a semi-structured interview helps the researcher make sure that the certain topics will be discussed (Saunders et al., 2009).

The interviews discussed three main topics: the use of critical materials, risk factors connected with critical materials, and strategies taken to secure supply of critical materials. The interview questions were developed in line with the literature review. Interviews lasted between 40 and 90 minutes and were conducted via phone or face to face by the authors. In order to avoid investigator bias, interviews were conducted by at least two authors when it was possible. Not all authors participated in all interviews, and this enabled independent oversight during the analysis phase. As we conducted interviews with only one person per company, respondent bias was possible. In order to reduce this, various secondary data was also analysed (sustainability and annual reports, and other data available at companies' webpages). The interviews were recorded and transcribed with the permission of interviewees. The secondary data was reviewed in order to collect additional/supportive information on the same topics that were discussed during the interview.

\subsection{Data analysis}

The coding of the obtained data was performed with the goal of finding empirical evidence in relation to risk factors and mitigation strategies (Tables 5 and 6). Two approaches to coding were implemented: direct and indirect. Direct coding involves the risk factors mentioned in relation to critical materials (selection of risks caused by critical materials); or when a risk factor was followed by the corresponding mitigation strategies implemented by the company (connection between risk and mitigation strategies). Indirect coding has implications for the logical connection of data. For example, if a risk factor (suggested by a company) corresponds to a criticality factor from Table 5, then that risk factor is considered for the analysis even if the direct reference to critical materials is not mentioned. In such cases, the relationship with the critical materials is taken by default, as the selected companies use critical materials for product manufacturing.

Once the coding process was complete, the data was analysed from different perspectives and at different levels (Miles and Huberman, 1994):

- within each company, in order to investigate the presence of specific risk factors, connected to the use of critical materials and mitigation strategies,

- $\quad$ within each dimension of analysis (risk factors and mitigation strategies), in order to highlight commonalities and differences as suggested by different companies. 


\subsection{Trustworthiness of the study}

Some limitations of the present research should be mentioned, such as the use of one respondent per company and the different roles of respondents in different companies. Eight trustworthiness criteria (for qualitative inductive research) were used to estimate the rigour of the study: credibility, transferability, dependability, confirmability and integrity, taken from interpretive research approach (Guba, 1981; Hirschman, 1986; Wallendorf and Belk, 1989); and fit, understanding and generality, adopted from grounded theory (Strauss and Corbin, 1990). A similar set of criteria has been applied in qualitative research by, for example, Flint et al. (2002), Mollenkopf et al.(2007), Lin and Zhou (2011). Table 8 shows that the methodology employed met these criteria.

Table 8. Trustworthiness of the study

\begin{tabular}{|c|c|}
\hline Criteria and explanation & teps to address the criteria \\
\hline $\begin{array}{l}\text { Credibility (extent to which the results } \\
\text { appear to be acceptable representations } \\
\text { of the data) }\end{array}$ & $\begin{array}{l}\text { The interpretations of data obtained from both interviews and reports were } \\
\text { verified with the interviewees during and after the interviews. } \\
\text { Triangulation of data sources: interviews and reports. } \\
\text { No contradictory evidence was identified via triangulation of data sources. }\end{array}$ \\
\hline $\begin{array}{l}\text { Transferability (extent to which the } \\
\text { findings from a study in one context will } \\
\text { apply to other contexts) }\end{array}$ & $\begin{array}{l}\text { Selected companies represent variations in type of industries, employed } \\
\text { critical materials, company size. }\end{array}$ \\
\hline $\begin{array}{l}\text { Dependability (extent to which the } \\
\text { findings are unique to time and place; } \\
\text { the stability or consistency of } \\
\text { explanations) }\end{array}$ & $\begin{array}{l}\text { All interviewees are experienced managers who understand the operations } \\
\text { of their companies and are knowledgeable about the use of critical } \\
\text { materials, related risks and employed mitigation strategies. } \\
\text { Interviewees reflected as far back as } 7 \text { years. } \\
\text { Secondary data was reviewed as far back as } 13 \text { years. }\end{array}$ \\
\hline $\begin{array}{l}\text { Confirmability (extent to which } \\
\text { interpretations are the result of the } \\
\text { participants and the phenomenon as } \\
\text { opposed to researcher bias) }\end{array}$ & $\begin{array}{l}\text { Triangulation of data sources: interviews and reports. } \\
\text { The interpretation of data obtained from both interviews and reports was } \\
\text { verified with the interviewees during and after the interviews. } \\
\text { The findings were reviewed by all researchers independently and then } \\
\text { collectively. }\end{array}$ \\
\hline $\begin{array}{l}\text { Integrity (extent to which int } \\
\text { are influenced by misinforma } \\
\text { evasions by participants) }\end{array}$ & $\begin{array}{l}\text { Confidentiality assurance to participants. } \\
\text { No contradictory evidence was identified via triangulation of data sources. }\end{array}$ \\
\hline $\begin{array}{l}\text { Fit (extent to which findings fit with the } \\
\text { substantive area under investigation) }\end{array}$ & tuy. \\
\hline $\begin{array}{l}\text { Understanding (extent to which } \\
\text { participants accept results as possible } \\
\text { representations of their world) }\end{array}$ & $\begin{array}{l}\text { The interpretations of data obtained were verified with the interviewees } \\
\text { during and after the interviews. }\end{array}$ \\
\hline $\begin{array}{l}\text { Generality (extent to which findings } \\
\text { discover multiple aspects of the } \\
\text { phenomenon) }\end{array}$ & $\begin{array}{l}\text { Interviews are lasted sufficient length to obtain explicit replies on posed } \\
\text { questions (40-90 min). } \\
\text { Semi-structured interviews allow for some flexibility in the conversation, } \\
\text { do not set constraints for questions, and enable in-depth insights. }\end{array}$ \\
\hline
\end{tabular}




\section{Findings}

All companies interviewed faced materials criticality in different ways. Company C1 experienced significant price increases for rare earth oxides used for the production of automotive catalyst due to reduced export quotas in China. Company C2 is affected by the price volatility of rare earth elements and platinum group metals, as a result, the company's policy is to minimise the use of these materials in products. Only one supplier of niobium (in particular, alloy with niobium) is available on the market for company C3. Company C4 experienced a shortage of components due to the global lack of tantalum, which led to delivery delays. Company C5 takes measures to ensure the availability of materials for catalytic converters, and in particular, a program on platinum sourcing is being developed with a tier 1 supplier.

Tables 9 and 10 present evidence of risk factors associated with critical materials according to supply chain and supplier risk categories and employed mitigation strategies as indicated by interviewed companies. The codes mark the relevance to the risk factors and mitigation strategies from the framework of analysis.

Insert Table 9 about here

Insert Table 10 about here

\subsection{Materials criticality factors}

Supply risks relate to either price increase and fluctuations (component manufacturers C1, C2) or physical availability (final product manufacturers C4 and C5). Company C3 is an interesting case. It has a single supplier of niobium ("globally one supplier is commercially available”), and therefore, it is subject to the risks related to single supply sourcing, however, the company does not consider the monopolistic situation as a problem, because there is no evidence for geological scarcity of the metal ("there is no shortage of Niobium for the next 200 years").

The demand risks refer either to the customer's move to a lower cost product (component manufacturers C1, C2) or to demand variability (final product manufacturers C4 and C5). For example, Company C2 faced a situation when its customer changed the product design to decrease costs related to rare earth elements. As a result, C2's component was ruled out of the final product due to a change to another technology, even though the component itself did not contain critical materials. 
Risks related to competition were indicated in relation to the product market (C2 and C4), items for recycling (C1) and availability of components (C4). Company C4 experienced competition in both product price and availability of components. Company C2 faces price pressure from two frontiers: the price volatility of rare earth elements and competition on price at the product market.

Geopolitical risks were present only in the case of C1, when China reduced export quotas for rare earth elements in 2011. Policy/regulatory risks are mirrored by sustainability risks and defined by environmental legislation that affected the interviewed companies (e.g. directives on waste management for end of life electronics (WEEE) and vehicles (ELV), and control of hazardous materials (REACH, RoHS)). Sustainability risks also include concerns over social and health issues, such as in relation to conflict metals. The sustainability risk category within supplier risks is directly linked to the same category within supply chain risks due to the cross-tier effects of environmental legislation and increasing attention (and obligations) to sustainable procurement.

No risk factors related to critical materials were indicated in the internal operations and information risk categories (except for C5). The same is true for supplier risks related to business, capabilities and relationships categories. Only concerns over supplier performance were noted by companies C2, C4 and C5.

Companies C2, C4 and C5 consider materials criticality as a set of both supply chain and supplier risk factors (where supply chain risk factors dominate). Companies C1 and C3 only indicated supply chain risk factors, although all companies have established strategies to address supplier-related risks. The companies interviewed thus acknowledge the complexity of the materials criticality phenomenon, where multiple actors (not just suppliers) are involved.

\subsection{Strategies to mitigate materials criticality}

Various mitigation strategies were employed, however, the interviewed companies paid much attention to managing the backward supply chain via multiple sourcing in different companies and locations and long-term relationships with suppliers. Only C1 indicated the importance of the material stream coming from its recycling operations, as it allows C1 to be less dependent on the suppliers of materials. Substitutability and recycling were not indicated as feasible economicviable options. Companies mentioned the use of recycled materials (other than CRM) (C2), but a recycler was not considered in the same way as a supplier due to the lower quality of available recycled materials, their low volumes etc. Recycling is considered a means to decrease the impact on the environment by C4 and C5 and to comply with obligations 
to manage product end-of-life (WEEE and ELV directives). C2 and C3 do not consider recycling as an attractive and feasible option.

The mitigation strategies correspond to all types of strategies in the classification of Manuj and Mentzer (2008), except for postponement. No company suggested such a strategy for ensuring the supply of critical materials. Control/share/transfer is the most dominant strategy type; while hedging via multiple sourcing and avoidance via supplier audit are the most common strategies among the interviewed companies. Security strategies comprise the metal prices monitoring (C1, C2) or increasing transparency in the supply chain (C5). The mitigation strategy that most commonly did not fit the classification by Manuj and Mentzer (2008) was sustainable procurement primary directed towards the elimination of hazardous materials. Actions for improving material efficiency and substitution are taken by companies C1 and C2. Companies C1 and C5 established dialogue with public authorities for legislation development. None of the companies in the study has established practices to assess constraints on the availability of purchased materials/components in the way it was presented by the European Commission (2010), for example.

\section{Discussion}

This section is divided into three parts corresponding to the research questions and highlighting the relationship of the collected evidence to the existing discourse on materials criticality.

\subsection{Materials criticality factors from manufacturer perspectives: differences in scope and business interdependencies}

The data collected provided evidence for different scopes of risk factors related to demand, competition and supplier performance when examined from the manufacturer's perspective. The criticality factors related to the demand category increase primarily from the dependence on customers and the risk of losing them due to cost increases or delivery delays rather than demand increases as suggested in the literature. In the competition category, competing demand for purchased materials and sensitivity to price fluctuations were not explicitly indicated. Instead, the interviewed companies highlighted the presence of competition om both sides: material price increase/availability of components and competition on price at the product market. Risk factors from the supplier performance category do not relate to the physical availability of materials; companies highlight the material/component quality, flexibility to respond to the changes in the market and ability to meet customer requirements. 
The findings suggest the existence of interdependences between markets, applications and companies. When a company (or even an industry) constitutes a small share of total material consumption, it cannot influence a material's market and follows the "big” players (main material consumers), adjusting to the changes in the market. For example, $8 \%$ of niobium is used for production of superalloys and 86\% for steel production (various applications) (European Commission, 2014b). This difference shapes the various perceptions on the criticality of materials in different industries and companies and determines the limits for possible actions. For example, C3's use of niobium is within that 8\%, and the company noted in the interview that it cannot influence the material's market, it just follows the market changes. The same was noted by $\mathrm{C} 4$ in relation to the critical materials contained in the purchased components. This information lets us imply the existence of cross-application mechanisms (interdependence) between companies across different industries (markets, applications) where the same material is applied; and where there are leaders (main material consumers), who shape the market conditions, and followers, who adjust to them. Cross-application interdependence should be considered as an additional materials criticality factor. This factor highlights the importance of analysing materials criticality at the industrial system level, but also suggests the importance of understanding the positions and roles of different players, and their interconnections.

Criticality factors such as geological unavailability, limited production and the capacity of mine and smelter, or the byproduct character of material are not considered by companies. There is no evidence for risk factors from the internal operations category, although the literature provides at least three of those factors. Neither literature, nor interviewed companies suggest risk factors linked to supplier business viability, capability and relations, which would be relevant to materials criticality. This implies that the companies do not tend to track the problem back to its origin via several tiers of suppliers; nor consider internal operations as possible causes of materials criticality. It appears that the interviewed companies do not distinguish many risk factors from suppliers; however, the supplier audit that is in place in all companies serves as a control instrument. This somehow limited consideration of sources of criticality factors can considerably limit the awareness of companies about materials criticality and constrain their ability to develop appropriate mitigation actions.

\subsection{A limited portfolio of implemented mitigation strategies}


The interviews and secondary data provide evidence that companies employ strategies that are not considered in the literature on materials criticality, but that are typical in the purchasing and supply management literature. For example, in the control/share/transfer category long-term contracts with suppliers are distinguished by the interviewed companies, however, more attention was paid to building long-term relationships, partnerships and alliances with both suppliers and customers, which was not discussed in the materials criticality literature. The same is true of the supplier audit that is a common strategy in avoidance category. These strategies serve as additional instruments that can aid the mitigation of materials criticality at the company level. In general, the manufacturers involved in our study secure the supply of materials and components primarily via supply and supplier management, which is in line with the findings of Peck and Bakker (2012) and Mroueh et al. (2014).

Many strategies listed in the literature are not employed by the interviewed companies. This suggests that those strategies are either not feasible, such as recycling and substitution, or not relevant for the business, such as the exploration of new sources, recycling, efficient mining, and international collaborations. This calls for selective governance interventions for providing support and incentives for specific companies to implement strategies that are considered important, such as recycling and closing the loop. As materials criticality is a complex phenomenon caused by the interplay of different actors, a single company cannot completely mitigate the risk by itself.

Although the companies interviewed faced temporal supply disruptions caused by materials criticality (C1: a price hike of rare earth oxides in 2011; C4: shortage of components due to lack of tantalum in 2010), the employed strategies have a permanent character leading to the revision of supply and supplier management, or the initiation of collaborative research projects. This suggests that companies consider the possibility of similar supply disruption events in the future and choose to address it proactively. Indeed, Alonso et al. (2007) noted that materials criticality could be mitigated only if addressed proactively. In general, the wide range of strategies employed by companies can serve as an indicator of their overall awareness of and capacity to mitigate materials criticality.

\subsection{Materials criticality transforms along the supply chain}

Different companies suggested different risk factors in the same risk categories. In particular, this difference is evident between component and final product manufacturers. Materials criticality transforms along the supply chain, leading to different views of materials criticality and mitigation strategies applied by companies. While component manufacturers 
$(\mathrm{C} 1, \mathrm{C} 2)$ are more concerned about price increase/fluctuations; final product manufacturers $(\mathrm{C} 4, \mathrm{C} 5)$ are more concerned about the physical availability of components and delivery times. Accordingly, there are also differences in mitigation strategies. While component manufacturers (C1, C2) pay attention to materials price risk monitoring and efficient use of materials; final product manufacturers (C4, C5) make their efforts in supply chain transparency and flexible production. Strategies for mitigation risks in the information category were oriented towards metal price monitoring (component manufacturers C1, C2) or enhancing supply chain visibility (final product manufacturers C4 and C5). Table 10 lists the characteristics of companies leading to the differences indicated above.

Table 11. Differences between characteristics of component and final product manufacturing companies.

\begin{tabular}{|l|l|}
\hline Component manufacturer & Final product manufacturer \\
\hline -Critical materials are purchased directly (as materials) & -Critical materials are purchased mostly indirectly (through \\
-Consume few materials & components) \\
& -Consume many materials (greater variety in comparison to \\
& component manufacturer) \\
-Dependent on changes in final product design & -Interested in functionality (physical and chemical \\
-Dependent on requirements of final product & characteristics) of components, not their consistency \\
\hline
\end{tabular}

Based on the results obtained it is possible to suggest that component manufacturers are exposed to a higher variety of risk factors, however, market position and the severity of competition contribute significantly to materials criticality and may either leverage or worsen it. An example of "leveraging” could be the case of company C1 that managed to incorporate an increase in materials cost into the product price and, therefore, "pass" the effect of materials criticality to its customers (risk transfer strategy). Company C3 is another example: the company does not consider the availability of a sole source of niobium troublesome. Company C2 may serve as an example of "worsening" of materials criticality. Although C2 experienced a price increase of materials, it cannot increase the price of its products due to strong market competition. C2 therefore, plays the role of a buffer against material criticality in the supply chain.

These findings suggest that being the supply chain position a contingent factor for materials criticality determination and mitigation, it has an impact at the national level as well. Indeed, different countries have different sets of industrial sectors and positions (stronger or weaker) within global supply chains (e.g. upstream or downstream).

\section{Conclusion}


At first sight, the scope of materials criticality factors established in the industrial system is much broader in comparison with the scope of considerations of manufacturing companies, which appears to be limited to first tier suppliers and customers, however, closer examination of the factors relevant to manufacturing companies suggests the existence of complex interconnections between companies within and between different supply chains (industries, markets), where the same critical materials are applied. None of the existing studies known to us have incorporated these particularities in criticality assessment. Our findings suggest the need to reconsider or expand the current research approach to include the manufacturer perspective, because it is impossible to provide viable implications for the industrial system level if the understanding of its players is not complete.

The findings suggest a certain capacity of companies to mitigate materials criticality, however, the companies we interviewed rely on backward supply chains and rarely went beyond supply/supplier management, although the literature offers a prominent arsenal of multiple strategies that could be applied to mitigate materials criticality. Such a limited set of employed strategies may suggest either their proved efficiency or an inertia of strategy application, when commonly used strategies are also applied for new issues, such as materials criticality. a better understanding of the grounds for decision making regarding mitigating materials criticality is required. It should also be noted that governance interventions might be required to provide support and incentives for strategies, which are currently regarded as irrelevant or challenging at the company level, but are important at the industrial system level (e.g. recycling and closing the loop).

Raising awareness in companies about operations in the broader supply chain and complementing materials criticality analysis with mechanisms related to company interconnections could improve the identification and mitigation of materials criticality.

The study suggests several opportunities for further research. It is necessary, firstly, to enlarge the study of manufacturers by involving more companies that vary in their position in the supply chain, industry, product, company size etc., in order to better understand how the internal and external characteristics of a company shape the notion of materials criticality and strategies for supply security. Secondly, it could be worth engaging the views of a broader set of decision makers within companies, belonging to different departments, so as to offer multiple (and maybe conflicting) perspectives on the topic, and opportunities for further business development. Thirdly, the study has been limited to manufacturers, but implications of materials criticality for other industrial stakeholders in supply chains (e.g. miners and recyclers) should 
be further explored. Finally, cross-tier effects and the interdependencies between different stakeholders and materials applications are worth a thorough investigation in order to gain a complete view of the scope of materials criticality impacts, and the mitigation options offered by multiple interactions in industrial dynamics. 
Table 1. Materials criticality factors

\begin{tabular}{|c|c|}
\hline Materials criticality factor & Description and references \\
\hline Economic importance & $\begin{array}{l}\text { enabling security or economic growth (Morley and Eatherley, 2008), (European } \\
\text { Commission, 2014a, 2010), (Graedel et al., 2012), } \\
\text { impact of a supply restriction (NRC, 2008), } \\
\text { percentage of revenue impacted (Graedel et al., 2012), (Slowinski et al., 2013), } \\
\text { importance to corporate strategy (Graedel et al., 2012) }\end{array}$ \\
\hline $\begin{array}{l}\text { Sensitivity to price } \\
\text { fluctuation }\end{array}$ & $\begin{array}{l}\text { the sensitivity of the product's cost to the cost of the material (influences price } \\
\text { elasticity of demand) (U.S. Department of Energy, 2011), } \\
\text { ability to pass-through cost increase (Graedel et al., 2012), (Slowinski et al., } \\
\text { 2013) }\end{array}$ \\
\hline $\begin{array}{l}\text { Price increase and } \\
\text { fluctuations }\end{array}$ & $\begin{array}{l}\text { (Morley and Eatherley, 2008), (Gleich et al., 2013), (Rosenau-Tornow et al., } \\
\text { 2009), (Slowinski et al., 2013), (U.S. Department of Energy, 2011), (Alonso et } \\
\text { al., 2007), (Mroueh et al., 2014), (Hatayama and Tahara, 2015) referring to } \\
\text { Japan's government (NEDO, 2009) }\end{array}$ \\
\hline Demand growth & $\begin{array}{l}\text { (Morley and Eatherley, 2008), (Moss et al., 2011), (Moss et al., 2013), (U.S. } \\
\text { Department of Energy, 2010), (NRC, 2008), (Buchert et al., 2009), (Rosenau- } \\
\text { Tornow et al., 2009), (Slowinski et al., 2013), (Mroueh et al., 2014), (Hatayama } \\
\text { and Tahara, 2015) referring to Japanese government (NEDO, 2009) }\end{array}$ \\
\hline $\begin{array}{l}\text { Competing demand for a } \\
\text { material }\end{array}$ & $\begin{array}{l}\text { (U.S. Department of Energy, 2010), (Nieto et al., 2013) } \\
\text { \% of world supply(Slowinski et al., 2013), } \\
\text { intensity of competition (Graedel et al., 2012), } \\
\text { distribution of applications and companies that use a given material (demand } \\
\text { diversity increases efficiency) (Alonso et al., 2007) }\end{array}$ \\
\hline $\begin{array}{l}\text { Low/impossible } \\
\text { substitutability (a substitute } \\
\text { is not available on the } \\
\text { market) }\end{array}$ & $\begin{array}{l}\text { (European Commission, 2014a, 2010), (Morley and Eatherley, 2008), (U.S. } \\
\text { Department of Energy, 2010), (U.S. Department of Energy, 2011), (NRC, 2008), } \\
\text { (Rosenau-Tornow et al., 2009), (Graedel et al., 2012), (British Geological } \\
\text { Survey, 2012), (Slowinski et al., 2013) }\end{array}$ \\
\hline Inability to innovate & $\begin{array}{l}\text { (Graedel et al., 2012); ability to substitute (Slowinski et al., 2013), R\&D budget } \\
\text { (Slowinski et al., 2013) }\end{array}$ \\
\hline $\begin{array}{l}\text { Instability of the producing } \\
\text { country (geopolitical risk) }\end{array}$ & $\begin{array}{l}\text { (European Commission, 2014a, 2010), (Moss et al., 2011), (Moss et al., 2013), } \\
\text { (U.S. Department of Energy, 2010), (Rosenau-Tornow et al., 2009), (Graedel et } \\
\text { al., 2012), (Slowinski et al., 2013), (British Geological Survey, 2012), (Mroueh } \\
\text { et al., 2014), } \\
\text { International trade environment (Nieto et al., 2013), } \\
\text { Privileged supply to own or other countries (Morley and Eatherley, 2008) }\end{array}$ \\
\hline $\begin{array}{l}\text { High concentration in } \\
\text { producing countries }\end{array}$ & $\begin{array}{l}\text { (European Commission, 2014a, 2010), (Morley and Eatherley, 2008), (Moss et } \\
\text { al., 2011), (Moss et al., 2013), (U.S. Department of Energy, 2010), (Buchert et } \\
\text { al., 2009), (Rosenau-Tornow et al., 2009), (Slowinski et al., 2013), (British } \\
\text { Geological Survey, 2012), (Nieto et al., 2013), (Alonso et al., 2007), (Hatayama } \\
\text { and Tahara, 2015), (NEDO, 2009) }\end{array}$ \\
\hline $\begin{array}{l}\text { High concentration in } \\
\text { producing companies }\end{array}$ & $\begin{array}{l}\text { (U.S. Department of Energy, 2010), (Rosenau-Tornow et al., 2009), (Slowinski } \\
\text { et al., 2013), (Nieto et al., 2013), (Alonso et al., 2007), (Mroueh et al., 2014), } \\
\text { (Hatayama and Tahara, 2015) referring to Japan’s government (NEDO, 2009) }\end{array}$ \\
\hline
\end{tabular}




\begin{tabular}{|c|c|}
\hline $\begin{array}{l}\text { Low/impossible } \\
\text { recyclability (low recycling } \\
\text { rate, volume, efficiency) }\end{array}$ & $\begin{array}{l}\text { (European Commission, 2014a, 2010), (Morley and Eatherley, 2008), (Moss et } \\
\text { al., 2011), (Moss et al., 2013), (NRC, 2008), (Buchert et al., 2009), (Rosenau- } \\
\text { Tornow et al., 2009), (British Geological Survey, 2012), (Alonso et al., 2007), } \\
\text { (Hatayama and Tahara, 2015) referring to Japan’s government (NEDO, 2009) }\end{array}$ \\
\hline $\begin{array}{l}\text { Geological unavailability } \\
\text { (depletion time, ore grade) }\end{array}$ & $\begin{array}{l}\text { (Morley and Eatherley, 2008), (NRC, 2008), (Buchert et al., 2009), (U.S. } \\
\text { Department of Energy, 2010), (Graedel et al., 2012), (Slowinski et al., 2013), } \\
\text { (British Geological Survey, 2012), (Alonso et al., 2007), (Hatayama and Tahara, } \\
\text { 2015) referring to Japan’s government (NEDO, 2009) }\end{array}$ \\
\hline $\begin{array}{l}\text { Long time to expand } \\
\text { production capacity } \\
\text { (exploration of new sources) }\end{array}$ & (Moss et al., 2011), (Moss et al., 2013), (Buchert et al., 2009) \\
\hline $\begin{array}{l}\text { Lack of investments in } \\
\text { exploration of new sources }\end{array}$ & $\begin{array}{l}\text { (Rosenau-Tornow et al., 2009), (Nieto et al., 2013), (Alonso et al., 2007), } \\
\text { (Mroueh et al., 2014), (Hatayama and Tahara, 2015) referring to Japan’s } \\
\text { government (NEDO, 2009) }\end{array}$ \\
\hline $\begin{array}{l}\text { Limited production and } \\
\text { capacity of mine, smelter, } \\
\text { refinery, freight }\end{array}$ & (Rosenau-Tornow et al., 2009);(U.S. Department of Energy, 2010) \\
\hline $\begin{array}{l}\text { Lack of stock at exchanges, } \\
\text { producers and } \\
\text { manufacturers }\end{array}$ & $\begin{array}{l}\text { (Rosenau-Tornow et al., 2009), (Hatayama and Tahara, 2015) referring to } \\
\text { Japan’s government (NEDO, 2009) }\end{array}$ \\
\hline $\begin{array}{l}\text { By-product character/ } \\
\text { coproduction }\end{array}$ & $\begin{array}{l}\text { (Moss et al., 2011), (Moss et al., 2013), (U.S. Department of Energy, 2010), } \\
\text { (NRC, 2008), (Buchert et al., 2009), (Rosenau-Tornow et al., 2009), (Graedel et } \\
\text { al., 2012), (Slowinski et al., 2013) }\end{array}$ \\
\hline $\begin{array}{l}\text { Social and environmental } \\
\text { restrictions }\end{array}$ & $\begin{array}{l}\text { Potential for environmental measures that may constrain access to deposits or the } \\
\text { supply of raw materials (European Commission, 2014a, 2010), } \\
\text { social and environmental restrictions (Rosenau-Tornow et al., 2009), } \\
\text { environmental regulations (Nieto et al., 2013) }\end{array}$ \\
\hline $\begin{array}{l}\text { Damage to health and } \\
\text { ecosystems }\end{array}$ & $\begin{array}{l}\text { damage to health and ecosystem (Graedel et al., 2012), } \\
\text { vulnerability to climate change, associated environmental impact (Morley and } \\
\text { Eatherley, 2008) }\end{array}$ \\
\hline
\end{tabular}


Table 2. Materials criticality mitigation strategies

\begin{tabular}{|c|c|}
\hline $\begin{array}{l}\text { Materials criticality mitigation } \\
\text { strategy }\end{array}$ & References \\
\hline $\begin{array}{l}\text { Exploration of new sources, } \\
\text { geological research } \\
\text { Increased mining of primary } \\
\text { resources }\end{array}$ & $\begin{array}{l}\text { (Erdmann and Graedel, 2011), (ETP SMR, 2013), (European Commission, } \\
\text { 2010), (Moss et al., 2013), (Buijs and Sievers, 2012), (U.S. Department of } \\
\text { Energy, 2010), (Speirs and Gross, 2014), (Graedel et al., 2014), (Alonso et al., } \\
\text { 2007) }\end{array}$ \\
\hline $\begin{array}{l}\text { Eco-efficient mining/refining; } \\
\text { new technology development }\end{array}$ & $\begin{array}{l}\text { mining/refining (Wäger et al., 2012), extraction technologies, processing } \\
\text { technologies (ETP SMR, 2013), (Moss et al., 2013), (Weiser et al., 2015), } \\
\text { (European Commission, 2010), } \\
\text { efficient by-product recovery (Moss et al., 2011), (Prior et al., 2013) }\end{array}$ \\
\hline $\begin{array}{l}\text { Increase of product } \\
\text { manufacturing efficiency }\end{array}$ & $\begin{array}{l}\text { (Weiser et al., 2015), (Erdmann and Graedel, 2011), (European Commission, } \\
\text { 2010), (Graedel et al., 2014), resource management control (Moss et al., 2013), } \\
\text { (Alonso et al., 2007) }\end{array}$ \\
\hline Increase of materials efficiency & $\begin{array}{l}\text { (Wäger et al., 2012), (Weiser et al., 2015), (ETP SMR, 2013), (Erdmann and } \\
\text { Graedel, 2011), (European Commission, 2010), (Buijs and Sievers, 2012), } \\
\text { (Morley and Eatherley, 2008), (Graedel et al., 2014), (Slowinski et al., 2013) }\end{array}$ \\
\hline $\begin{array}{l}\text { Product design for disassembly/ } \\
\text { recycling }\end{array}$ & $\begin{array}{l}\text { (Wäger et al., 2012), eco-design (Weiser et al., 2015), design for recycling } \\
\text { (Moss et al., 2013), design for recycling (U.S. Department of Energy, 2010), } \\
\text { eliminate CRM, use of recycled materials (Graedel et al., 2014), alternative } \\
\text { design without CRM (Slowinski et al., 2013) }\end{array}$ \\
\hline Leasing & (Wäger et al., 2012), commodity as a service (Prior et al., 2013) \\
\hline Substitution & $\begin{array}{l}\text { manufacturing (Wäger et al., 2012); (Weiser et al., 2015), (ETP SMR, 2013), } \\
\text { (Erdmann and Graedel, 2011), (European Commission, 2010), (Moss et al., } \\
\text { 2011), (Moss et al., 2013), (Buijs and Sievers, 2012), (U.S. Department of } \\
\text { Energy, 2010), (Morley and Eatherley, 2008), (Speirs and Gross, 2014), } \\
\text { (Graedel et al., 2014), (Alonso et al., 2007) }\end{array}$ \\
\hline $\begin{array}{l}\text { Recycling (mining and } \\
\text { manufacturing scrap, end of life } \\
\text { products, end of use products) }\end{array}$ & $\begin{array}{l}\text { (Wäger et al., 2012), (Erdmann and Graedel, 2011), (European Commission, } \\
\text { 2010), (Weiser et al., 2015), (U.S. Department of Energy, 2010), (Erdmann and } \\
\text { Graedel, 2011), (Moss et al., 2013), (Buijs and Sievers, 2012), (Fizaine, 2013), } \\
\text { (Bustamante and Gaustad, 2014), (Henckens et al., 2014), (Slowinski et al., } \\
\text { 2013), (Alonso et al., 2007) }\end{array}$ \\
\hline $\begin{array}{l}\text { Improvement of recycling } \\
\text { technologies }\end{array}$ & $\begin{array}{l}\text { (Weiser et al., 2015), (ETP SMR, 2013), (European Commission, 2010), (Moss } \\
\text { et al., 2011), (Moss et al., 2013), (U.S. Department of Energy, 2010), (Graedel } \\
\text { et al., 2014) }\end{array}$ \\
\hline $\begin{array}{l}\text { Eco-efficient end of life product } \\
\text { collection and recovery systems }\end{array}$ & $\begin{array}{l}\text { recycling/disposal (Wäger et al., 2012), (ETP SMR, 2013), (European } \\
\text { Commission, 2010), (Moss et al., 2011), (Moss et al., 2013), } \\
\text { recycling chain interfaces (Wäger et al., 2012), (ETP SMR, 2013), (Alonso et } \\
\text { al., 2007) }\end{array}$ \\
\hline Reuse and remanufacturing & (Moss et al., 2013), lifecycle management (Weiser et al., 2015) \\
\hline
\end{tabular}




\begin{tabular}{|c|c|}
\hline Closing supply chain loops & (Morley and Eatherley, 2008), (Bell et al., 2012), (Bell et al., 2013) \\
\hline Stockpiling & $\begin{array}{l}\text { (Erdmann and Graedel, 2011), (Moss et al., 2013), (U.S. Department of } \\
\text { Energy, 2010), (Speirs and Gross, 2014), (Graedel et al., 2014), } \\
\text { storage of scrap (Fizaine, 2013), (Wäger et al., 2012), (Alonso et al., 2007) }\end{array}$ \\
\hline $\begin{array}{l}\text { Increase of product lifetime (use } \\
\text { product longer) }\end{array}$ & (Wäger et al., 2012), (Buijs and Sievers, 2012), (Henckens et al., 2014) \\
\hline $\begin{array}{l}\text { Diversification of suppliers } \\
\text { Shift to low risk countries }\end{array}$ & $\begin{array}{l}\text { (Erdmann and Graedel, 2011), (U.S. Department of Energy, 2011), (U.S. } \\
\text { Department of Energy, 2010) }\end{array}$ \\
\hline $\begin{array}{l}\text { Long-term contracts with } \\
\text { suppliers }\end{array}$ & (U.S. Department of Energy, 2011), (Graedel et al., 2014) \\
\hline $\begin{array}{l}\text { Development of supply chain } \\
\text { and cross industry interfaces } \\
\text { (including joint-ventures, } \\
\text { vertical and horizontal } \\
\text { integrations and collaborations) }\end{array}$ & $\begin{array}{l}\text { (Moss et al., 2011), (U.S. Department of Energy, 2011), (Erdmann and } \\
\text { Graedel, 2011), (Weiser et al., 2015), (Slowinski et al., 2013) }\end{array}$ \\
\hline $\begin{array}{l}\text { Increase of transparency and } \\
\text { traceability along the SC }\end{array}$ & $\begin{array}{l}\text { (Wäger et al., 2012), (Weiser et al., 2015), (Moss et al., 2013), (Slowinski et } \\
\text { al., 2013), (Alonso et al., 2007) }\end{array}$ \\
\hline $\begin{array}{l}\text { Identification and assessment of } \\
\text { materials criticality }\end{array}$ & (Slowinski et al., 2013), (Alonso et al., 2007) \\
\hline $\begin{array}{l}\text { Sustainability standards (in } \\
\text { mining) }\end{array}$ & (Wäger et al., 2012), (Moss et al., 2013), (Weiser et al., 2015) \\
\hline Certification/labelling & mining/refining and recycling/disposal (Wäger et al., 2012) \\
\hline $\begin{array}{l}\text { Data collection and } \\
\text { dissemination (information } \\
\text { exchange) }\end{array}$ & $\begin{array}{l}\text { (Weiser et al., 2015), (Moss et al., 2011), (Moss et al., 2013), (Slowinski et al., } \\
\text { 2013), (Alonso et al., 2007) }\end{array}$ \\
\hline $\begin{array}{l}\text { Data sharing between different } \\
\text { countries, international } \\
\text { collaborations }\end{array}$ & (Moss et al., 2011), (Moss et al., 2013) \\
\hline International diplomacy & $\begin{array}{l}\text { (Speirs and Gross, 2014), (U.S. Department of Energy, 2010) } \\
\text { revision of international trade policies (minimizing export restrictions) } \\
\text { (Erdmann and Graedel, 2011) }\end{array}$ \\
\hline $\begin{array}{l}\text { Consumer education and } \\
\text { awareness programs }\end{array}$ & governance interventions (Weiser et al., 2015) \\
\hline
\end{tabular}


Table 3. Supply chain risk categories

\begin{tabular}{|c|c|c|}
\hline $\begin{array}{l}\text { Supply chain } \\
\text { risk category }\end{array}$ & Examples & References \\
\hline Supply & $\begin{array}{ll}\text { - Supply market: } \\
\text { o } & \text { Price fluctuations } \\
\text { o } & \text { Small number of available suppliers } \\
\text { o } & \text { Lack of the purchased items on the market } \\
\text { o } & \text { Supplier strength at the market } \\
\text { o } & \text { High geographical concentration of suppliers } \\
\text { - Sourcing strategy } \\
\text { o } & \text { Small number of suppliers in supply base } \\
\text { o } & \text { Single sourcing } \\
\text { o } & \text { Global sourcing } \\
\end{array}$ & $\begin{array}{l}\text { (Rao and Goldsby, 2011), (Canbolat et al., 2008), } \\
\text { (Faisal, 2009), (Macurová and Jurásková, 2013), } \\
\text { (Wu et al., 2006), (Micheli et al., 2008), (Zsidisin, } \\
\text { 2003), (Tang and Musa, 2011), (Zsidisin et al., } \\
\text { 2004), (Cavinato, 2004), (Christopher and Peck, } \\
\text { 2011), (Tang, 2006b), (Govindan and Jepsen, } \\
\text { 2016), (Ho et al., 2015), (Bandaly et al., 2013), } \\
\text { (Day et al., 2010) }\end{array}$ \\
\hline Demand & $\begin{array}{ll}\text { - } & \text { Small customer base, customer dependency } \\
\text { - } & \text { Demand growth } \\
\text { - } & \text { Demand variability } \\
\text { - } & \text { Order variability } \\
\text { - } & \text { Reeting requirements of customers (design, quality, delivery time) } \\
\end{array}$ & $\begin{array}{l}\text { (Rao and Goldsby, 2011), (Canbolat et al., 2008), } \\
\text { (Faisal, 2009), (Wu et al., 2006), (Tang and Musa, } \\
\text { 2011), (Chopra and Sodhi, 2004), (Cavinato, } \\
\text { 2004), (Christopher and Peck, 2011), (Tang, } \\
\text { 2006b), (Ho et al., 2015), (Bandaly et al., 2013) }\end{array}$ \\
\hline $\begin{array}{l}\text { Internal } \\
\text { Operations }\end{array}$ & $\begin{array}{ll} & \text { Lack of technical capability } \\
\text { - } & \text { Lack of design capability } \\
\text { - } & \text { Lack of manufacturing capability, manufacturing breakdown } \\
\text { - } & \text { Inability to adapt to changes (capacity, technology, design, legislation etc.) } \\
\text { - } & \text { Inability to anticipate changes } \\
\end{array}$ & $\begin{array}{l}\text { (Rao and Goldsby, 2011), (Chopra and Sodhi, } \\
\text { 2004), (Cavinato, 2004), (Christopher and Peck, } \\
\text { 2011), (Bandaly et al., 2013) }\end{array}$ \\
\hline Information & $\begin{array}{ll}\text { - } & \text { Lack of visibility } \\
\text { - } & \text { Lack of transparency } \\
\text { - } & \text { Lack of information exchange (delay, lack) } \\
\text { - } & \text { Lack of information security } \\
\end{array}$ & $\begin{array}{l}\text { (Faisal, 2009), (Macurová and Jurásková, 2013), } \\
\text { (Tang and Musa, 2011), (Chopra and Sodhi, } \\
\text { 2004), (Cavinato, 2004), (Ho et al., 2015), } \\
\text { (Bandaly et al., 2013) }\end{array}$ \\
\hline Competition & $\begin{array}{l}\text { - Rivalry among existing firms (for product and/or material) - high competition in the } \\
\text { market } \\
\text { - } \quad \text { Lack of a possibility to differentiate the product from the competitors } \\
\text { - New entrants }\end{array}$ & (Rao and Goldsby, 2011), (Ho et al., 2015) \\
\hline $\begin{array}{l}\text { Regulations/ } \\
\text { Policy }\end{array}$ & $\begin{array}{ll}\text { - } & \text { Environmental regulations } \\
\text { - } & \text { Trade policy (export quotas) } \\
\text { - } & \text { Resource nationalism }\end{array}$ & $\begin{array}{l}\text { (Rao and Goldsby, 2011), (Wu et al., 2006), } \\
\text { (Christopher and Peck, 2011), (Bandaly et al., } \\
\text { 2013) }\end{array}$ \\
\hline
\end{tabular}




\begin{tabular}{|l|l|l|l|}
\hline Geopolitical & $\bullet \quad$ Political uncertainty and instability & $\begin{array}{l}\text { (Rao and Goldsby, 2011), (Macurová and } \\
\text { Jurásková, 2013), (Wu et al., 2006), (Tang and } \\
\text { Musa, 2011), (Tang, 2006b), (Ho et al., 2015), } \\
\text { (Bandaly et al., 2013) }\end{array}$ \\
\hline Sustainability & $\bullet \quad$ Impact on environment, health and safety & (Tang and Musa, 2011) \\
\hline
\end{tabular}

Table 4. Supplier risk categories.

\begin{tabular}{|c|c|c|}
\hline $\begin{array}{l}\text { Supplier risk } \\
\text { category }\end{array}$ & Examples & References \\
\hline Business & Financial and ownership instability of a supplier & $\begin{array}{l}\text { (Faisal, 2009), (Macurová and Jurásková, 2013), (Wu et al., 2006), (Micheli et } \\
\text { al., 2008), (Chopra and Sodhi, 2004), (Govindan and Jepsen, 2016), (Bandaly } \\
\text { et al., 2013), (Day et al., 2010), (Ho et al., 2010), (Govindan et al., 2013) }\end{array}$ \\
\hline Performance & $\begin{array}{l}\text { Failure to meet buyer's requirements in relation to: } \\
\text { - delivery time, } \\
\text { - quality of purchased items, } \\
\text { - quantity of purchased items, } \\
\text { - price (increase, volatility, competitive pricing), } \\
\text { - flexibility (order variability) }\end{array}$ & $\begin{array}{l}\text { (Rao and Goldsby, 2011), (Canbolat et al., 2008), (Faisal, 2009), (Kull and } \\
\text { Talluri, 2008)(Kull and Talluri, 2008)(Kull and Talluri, 2008), (Macurová and } \\
\text { Jurásková, 2013), (Matook et al., 2009), (Wu et al., 2006), (Micheli et al., } \\
\text { 2008), (Zsidisin, 2003), (Tang and Musa, 2011), (Chopra and Sodhi, 2004), } \\
\text { (Zsidisin et al., 2004),, (Govindan and Jepsen, 2016), (Bandaly et al., 2013), } \\
\text { (Day et al., 2010), (Ho et al., 2010), (Govindan et al., 2013) }\end{array}$ \\
\hline Capabilities & $\begin{array}{l}\text { - Lack of technical capability } \\
\text { - Lack of design capability } \\
\text { - Lack of manufacturing capability } \\
\text { - Inability to adapt to changes (capacity, technology, } \\
\text { - design, legislation etc.) } \\
\text { - Inability to anticipate changes } \\
\text { - Low level of supplier certification } \\
\end{array}$ & $\begin{array}{l}\text { (Canbolat et al., 2008), (Faisal, 2009), (Matook et al., 2009), (Micheli et al., } \\
\text { 2008), (Govindan and Jepsen, 2016), (Hallikas et al., 2005), (Day et al., 2010), } \\
\text { (Ho et al., 2010), (Govindan et al., 2013) }\end{array}$ \\
\hline Relationship & $\begin{array}{l}\text { - Lack of information exchange, information asymmetry } \\
\text { - Opportunistic behaviour } \\
\text { - Reputation risk } \\
\text { - Liability risk } \\
\text { - Wrong supplier segmentation, selection }\end{array}$ & $\begin{array}{l}\text { (Faisal, 2009), (Rao and Goldsby, 2011), (Matook et al., 2009), (Micheli et al., } \\
\text { 2008), (Zsidisin et al., 2004), (Cavinato, 2004), (Govindan and Jepsen, 2016), } \\
\text { (Bandaly et al., 2013), (Hallikas et al., 2005), (Day et al., 2010), (Ho et al., } \\
\text { 2010), (Govindan et al., 2013) }\end{array}$ \\
\hline Sustainability & - Hazardous materials in product & $\begin{array}{l}\text { (Matook et al., 2009), (Micheli et al., 2008), (Tang and Musa, 2011), (Ho et al., } \\
\text { 2010), (Govindan et al., 2013) }\end{array}$ \\
\hline
\end{tabular}


Table 5. Classification of materials criticality factors under supply and supplier risk categories

\begin{tabular}{|c|c|}
\hline Risk category & Materials criticality factors \\
\hline \multicolumn{2}{|r|}{ Supply chain risk category } \\
\hline Supply & $\begin{array}{ll}\text { - } & \text { Price increase and fluctuations [Sup1] } \\
\text { - } & \text { High concentration in producing countries [Sup2] } \\
\text { - } & \text { High concentration in producing companies [Sup3] } \\
\text { - } & \text { Low/impossible substitutability (unavailability of substitutes at the market) [Sup4] } \\
\text { - } & \text { Low/impossible recyclability (unavailability of recycled material) [Sup5] } \\
\text { - } & \text { Geological unavailability: depletion, low ore grade [Sup6] } \\
\text { - } & \text { By-product character/ coproduction [Sup7] } \\
\text { - } & \text { Lack of investments in exploration of new sources [Sup8] } \\
\text { - } & \text { Long time to expand production capacity (exploration of new sources) [Sup9] } \\
\text { - } & \text { Lack of stocks [Sup10] } \\
\text { - } & \text { Sensitivity to price fluctuation [Sup11] }\end{array}$ \\
\hline Demand & - $\quad$ Demand growth [Dem1] \\
\hline Internal Operations & $\begin{array}{ll}\text { - } & \text { Low/impossible substitutability (inability to develop a substitute) [IO1] } \\
\text { - } & \text { Inability to innovate [IO2] } \\
\text { - } & \text { Economic importance [IO3] }\end{array}$ \\
\hline Information & $\mathrm{n} / \mathrm{a}$ \\
\hline Competition & $\begin{array}{ll}\text { - } & \text { Competing demand for a material [Com1] } \\
\text { - } & \text { Sensitivity to price fluctuation [Com2] }\end{array}$ \\
\hline Regulations/Policy & - $\quad$ Social and environmental restrictions [RP1] \\
\hline Geopolitical & $\begin{array}{l}\text { - } \quad \text { Instability of the producing country (geopolitical risk) [Geo1] } \\
\text { - } \quad \text { High concentration in producing countries [Geo2] }\end{array}$ \\
\hline Sustainability & - Damage to health and ecosystems [Sus/SC1] \\
\hline \multicolumn{2}{|r|}{ Supplier risk category } \\
\hline Business & $\mathrm{n} / \mathrm{a}$ \\
\hline Performance & $\begin{array}{l}\text { - Limited production and capacity of mine, smelter, refinery, freight [Per1] } \\
\text { - } \quad \text { Lack of stock [Per2] }\end{array}$ \\
\hline Capabilities & $\begin{array}{ll}\text { - } & \text { Low/impossible substitutability (inability to develop a substitute) [Cap1] } \\
\text { - } & \text { Inability to innovate [Cap2] } \\
\text { - } & \text { Lack of investment in exploration of new sources [Cap3] }\end{array}$ \\
\hline Relationship & $\mathrm{n} / \mathrm{a}$ \\
\hline Sustainability & - $\quad$ Damage to health and ecosystems [Sus/S1] \\
\hline
\end{tabular}


Table 6. Classification of materials criticality mitigation strategies according to risk mitigation strategies from Manuj and Mentzer (2008)

\begin{tabular}{|c|c|}
\hline $\begin{array}{l}\text { Risks mitigation } \\
\text { strategies }\end{array}$ & Materials criticality mitigation strategies \\
\hline Postponement & - $\mathrm{n} / \mathrm{a}$ \\
\hline Speculation & - $\quad$ Stockpiling [Spe1] \\
\hline Hedging & $\begin{array}{ll}- & \text { Diversification of suppliers [Hed1] } \\
\text { - } & \text { Shift to low risk countries [Hed2] }\end{array}$ \\
\hline Control/share/transfer & $\begin{array}{ll}\text { - } & \text { Long-term contracts with suppliers [CST1] } \\
\text { - } & \text { Develop supply chain and cross industry interfaces (including joint-ventures, } \\
\text { - } & \text { vertical and horizontal integrations and collaborations) [CST2] } \\
\text { - } & \text { Recyce and remanufacturing [CST3] } \\
\text { - } & \text { Products) [CST4] } \\
\text { - } & \text { Closing supply chement of recycling technologies [CST5] } \\
\end{array}$ \\
\hline Security & $\begin{array}{ll}\text { - } & \text { Increase transparency and traceability along the SC [Sec1] } \\
\text { - } & \text { Data collection and dissemination (information exchange) [Sec2] }\end{array}$ \\
\hline Avoidance & - Identification and assessment of materials criticality [Avo1] \\
\hline Other strategies & $\begin{array}{ll}\text { - } & \text { Exploration of new sources, geological research [Oth1] } \\
\text { - } & \text { Increased mining of primary resources [Oth2] } \\
\text { - } & \text { Eco-efficient mining/refining; new technology development [Oth3] } \\
\text { - } & \text { Increase of product manufacturing efficiency [Oth4] } \\
\text { - } & \text { Increase of materials efficiency [Oth5] } \\
\text { - } & \text { Product design for disassembly/recycling [Oth6] } \\
\text { - } & \text { Use of recycled materials [Oth7] } \\
\text { - } & \text { Leasing [Oth8] } \\
\text { - } & \text { Substitution [Oth9] } \\
\text { - } & \text { Eco-efficient end of life product collection and recovery systems [Oth10] } \\
\text { - } & \text { Increase of product lifetime (use product longer) [Oth11] } \\
\text { - } & \text { Sustainability standards (in mining) [Oth12] } \\
\text { - } & \text { Data sharing between different countries, international collaborations [Oth14] } \\
\text { - } & \text { International diplomacy [Oth15] } \\
\text { - } & \text { Consumer education and awareness programs [Oth16] }\end{array}$ \\
\hline
\end{tabular}


Table 9. Risks associated with critical materials

\begin{tabular}{|c|c|c|c|c|c|}
\hline & \begin{tabular}{|l|} 
C1 [recycler; material \\
and component \\
manufacturer]
\end{tabular} & $\begin{array}{l}\text { C2 [component } \\
\text { manufacturers] }\end{array}$ & $\begin{array}{l}\text { C3 [component } \\
\text { manufacturers] }\end{array}$ & C4 [final product manufacturer] & $\begin{array}{l}\text { C5 [component and final } \\
\text { product manufacturer] }\end{array}$ \\
\hline \multicolumn{6}{|c|}{ Supply chain risk category } \\
\hline Supply & $\begin{array}{ll}\text { - } & \text { Metal price } \\
\text { fluctuation } \\
\text { (Platinum Group } \\
\text { Metals, REE) [Sup1] }\end{array}$ & \begin{tabular}{|l} 
- \\
Materials price \\
increase (REE, \\
Platinum Group \\
Metals) [Sup1] \\
- No substitutes for \\
materials [Sup4] \\
- Sourcing from \\
different sources \\
affect quality/ \\
performance
\end{tabular} & $\begin{array}{l}\text { - Very concentrated } \\
\text { supply chain; niche } \\
\text { monopolistic } \\
\text { market; a single } \\
\text { supplier available } \\
\text { in the market } \\
\text { [Sup3] } \\
\text { - No substitutes } \\
\text { [Sup4] }\end{array}$ & 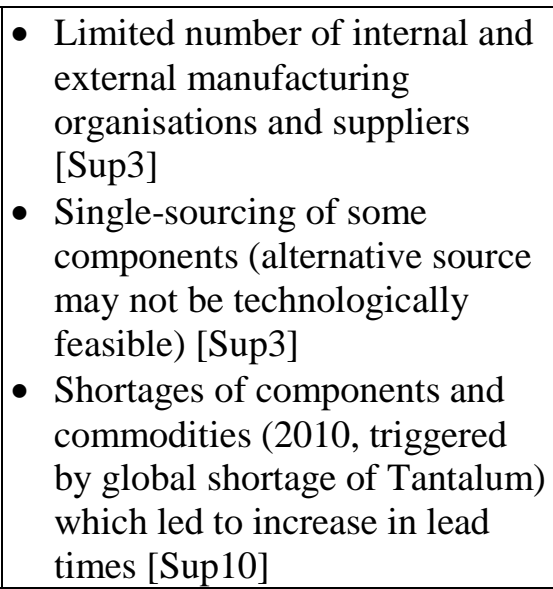 & $\begin{array}{l}\text { - } \text { Component shortages in } \\
\text { production [Sup10] } \\
\text { - Single sourcing [Sup3] }\end{array}$ \\
\hline Demand & $\begin{array}{l}\text { - } \begin{array}{l}\text { Customer's switch } \\
\text { to lower cost } \\
\text { product }\end{array} \\
\end{array}$ & $\begin{array}{l}\text { - Customer's } \\
\text { switch to lower } \\
\text { cost component } \\
\text { (change of the } \\
\text { final product } \\
\text { design) }\end{array}$ & - $\mathrm{n} / \mathrm{a}$ & $\begin{array}{l}\text { - Half revenue comes from ten } \\
\text { biggest companies } \\
\text { - Non-forecasted upside demand } \\
\text { [Dem1] } \\
\text { - Deterioration of delivery } \\
\text { capability (due to shortages of } \\
\text { components) }\end{array}$ & $\begin{array}{l}\text { - Fluctuations of demand } \\
\text { [Dem1] }\end{array}$ \\
\hline $\begin{array}{l}\text { Internal } \\
\text { operations }\end{array}$ & - $\mathrm{n} / \mathrm{a}$ & - $\mathrm{n} / \mathrm{a}$ & - $\mathrm{n} / \mathrm{a}$ & - $\mathrm{n} / \mathrm{a}$ & - $\mathrm{n} / \mathrm{a}$ \\
\hline Information & - $\mathrm{n} / \mathrm{a}$ & - $\mathrm{n} / \mathrm{a}$ & - $\mathrm{n} / \mathrm{a}$ & - $\mathrm{n} / \mathrm{a}$ & $\begin{array}{l}\text { Interruptions in critical } \\
\text { information systems. }\end{array}$ \\
\hline Competition & $\begin{array}{l}\text { - } \text { Lack of level } \\
\text { playing field for } \\
\text { recycling. } \\
\text { - } \text { Increased } \\
\text { competition for } \\
\text { items for recycling } \\
\text { operations and } \\
\text { produced products. }\end{array}$ & $\begin{array}{ll} & \text { Increasing } \\
\text { competition. } \\
\text { - } & \text { Price pressure. }\end{array}$ & - $\mathrm{n} / \mathrm{a}$ & $\begin{array}{l}\text { - Highly competitive } \\
\text { environment for products. } \\
\text { - Price pressure. } \\
\text { - Unusual allocation of } \\
\text { components to competitors } \\
\text { leading to shortages. }\end{array}$ & - Increasing competition. \\
\hline
\end{tabular}




\begin{tabular}{|c|c|c|c|c|c|}
\hline $\begin{array}{l}\text { Regulations/ } \\
\text { policy }\end{array}$ & $\begin{array}{l}\text { - Non-compliance } \\
\text { with REACH } \\
\text { regulations [RP1] }\end{array}$ & $\begin{array}{l}\text { - Non-compliance } \\
\text { with RoHS } \\
\text { regulations [RP1] }\end{array}$ & $\begin{array}{l}\text { - Non-compliance } \\
\text { with RoHS and } \\
\text { REACH } \\
\text { regulations [RP1] }\end{array}$ & $\begin{array}{l}\text { - Non-compliance with RoHS } \\
\text { and REACH regulations [RP1] } \\
\text { - Non-compliance with WEEE } \\
\text { directive [RP1] }\end{array}$ & $\begin{array}{ll} & \text { Non-compliance with } \\
\text { emission legislation } \\
\text { [RP1] } \\
\text { - } \\
\text { Non-compliance with } \\
\text { REACH legislation [RP1] } \\
\text { - Non-compliance with } \\
\text { ELV directive [RP1] } \\
\end{array}$ \\
\hline Geopolitical & $\begin{array}{l}\text { - } \text { Reduction in } \\
\text { Chinese export } \\
\text { quotas for rare earth } \\
\text { oxides in } 2011 \\
\text { [Geo1] } \\
\end{array}$ & - $\mathrm{n} / \mathrm{a}$ & - $\mathrm{n} / \mathrm{a}$ & - $\mathrm{n} / \mathrm{a}$ & - $\mathrm{n} / \mathrm{a}$ \\
\hline Sustainability & $\begin{array}{l}\text { - } \text { Non-compliance } \\
\text { with REACH } \\
\text { legislation } \\
\text { [Sus/SC1] } \\
\text { - Non-compliance } \\
\text { with Dodd Frank } \\
\text { Act on sourcing of } \\
\text { conflict materials } \\
\text { [Sus/SC1] }\end{array}$ & $\begin{array}{l}\text { - Non-compliance } \\
\text { with RoHS } \\
\text { regulations } \\
\text { [Sus/SC1] }\end{array}$ & $\begin{array}{l}\text { - Non-compliance } \\
\text { with California } \\
\text { Transparency in } \\
\text { Supply Chains Act } \\
\text { (slavery and } \\
\text { human trafficking) } \\
\text { [Sus/SC1] }\end{array}$ & $\begin{array}{l}\text { - } \text { Non-compliance with RoHS } \\
\text { and REACH regulations } \\
\text { [Sus/SC1] } \\
\text { - Non-compliance with WEEE } \\
\text { directive [Sus/SC1] } \\
\text { - Non-compliance with Dodd } \\
\text { Frank Act on sourcing of } \\
\text { conflict materials [Sus/SC1] }\end{array}$ & $\begin{array}{l}\text { - } \\
\text { Non- compliance with } \\
\text { emission legislation } \\
\text { [Sus/SC1] } \\
\text { - } \text { Non-compliance with } \\
\text { REACH legislation } \\
\text { [Sus/SC1] } \\
\text { - Non-compliance with ELV } \\
\text { directive [Sus/SC1] }\end{array}$ \\
\hline \multicolumn{6}{|c|}{ Supplier risk category } \\
\hline Business & $\bullet \mathrm{n} / \mathrm{a}$ & $\bullet \mathrm{n} / \mathrm{a}$ & $\bullet \mathrm{n} / \mathrm{a}$ & $\bullet \mathrm{n} / \mathrm{a}$ & $\bullet \mathrm{n} / \mathrm{a}$ \\
\hline Performance & $\bullet \mathrm{n} / \mathrm{a}$ & $\begin{array}{l}\text { - Failure to provide } \\
\text { required quality } \\
\text { of materials }\end{array}$ & $\bullet \mathrm{n} / \mathrm{a}$ & $\begin{array}{l}\text { - Failure to deliver or to perform } \\
\text { according to company's } \\
\text { requirements }\end{array}$ & $\begin{array}{l}\text { - Failure to provide required } \\
\text { quality of components. } \\
\text { - Failure to respond rapidly } \\
\text { to upturns and downturns } \\
\text { in demand. } \\
\end{array}$ \\
\hline Capabilities & $\bullet \mathrm{n} / \mathrm{a}$ & $\bullet \mathrm{n} / \mathrm{a}$ & $\bullet \mathrm{n} / \mathrm{a}$ & $\bullet \mathrm{n} / \mathrm{a}$ & $\bullet \mathrm{n} / \mathrm{a}$ \\
\hline Relationship & $\bullet \mathrm{n} / \mathrm{a}$ & $\bullet \mathrm{n} / \mathrm{a}$ & $\bullet \mathrm{n} / \mathrm{a}$ & $\bullet \mathrm{n} / \mathrm{a}$ & $\bullet \mathrm{n} / \mathrm{a}$ \\
\hline Sustainability & $\begin{array}{l}\text { - Non-compliance } \\
\text { with REACH } \\
\text { legislation [Sus/S1] } \\
\text { - Non-compliance } \\
\text { with Dodd Frank } \\
\text { Act on sourcing of } \\
\text { conflict materials } \\
\text { [Sus/S1] }\end{array}$ & $\begin{array}{l}\text { - Non-compliance } \\
\text { with RoHS } \\
\text { regulations } \\
\text { [Sus/S1] }\end{array}$ & \begin{tabular}{|l} 
- Non-compliance \\
with RoHS and \\
REACH \\
regulations \\
[Sus/S1] \\
- Non-compliance \\
with California \\
Transparency in \\
\end{tabular} & $\begin{array}{l}\text { - Non-compliance with RoHS } \\
\text { and REACH regulations } \\
\text { [Sus/S1] } \\
\text { - Non-compliance with Dodd } \\
\text { Frank Act on sourcing of } \\
\text { conflict materials [Sus/S1] }\end{array}$ & $\begin{array}{l}\text { - Non-compliance with } \\
\text { REACH legislation } \\
\text { [Sus/S1] }\end{array}$ \\
\hline
\end{tabular}




\begin{tabular}{|l|l|l|l|l|}
\hline & & $\begin{array}{l}\text { Supply Chains Act } \\
\text { (slavery and } \\
\text { human trafficking) } \\
\text { [Sus/S1] }\end{array}$ & \\
\hline
\end{tabular}

Table 10. Employed mitigation strategies

\begin{tabular}{|c|c|c|c|c|c|}
\hline $\begin{array}{l}\text { Mitigation } \\
\text { strategies }\end{array}$ & $\begin{array}{l}\text { C1 [recycler; material and } \\
\text { component manufacturer] }\end{array}$ & $\begin{array}{l}\text { C2 [component } \\
\text { manufacturers] } \\
\end{array}$ & $\begin{array}{l}\text { C3 [component } \\
\text { manufacturers] }\end{array}$ & $\begin{array}{l}\text { C4 [final product } \\
\text { manufacturer] }\end{array}$ & $\begin{array}{l}\text { C5 [component and final } \\
\text { product manufacturer] }\end{array}$ \\
\hline Postponement & $\mathrm{n} / \mathrm{a}$ & n/a & $\mathrm{n} / \mathrm{a}$ & $\mathrm{n} / \mathrm{a}$ & $\mathrm{n} / \mathrm{a}$ \\
\hline Speculation & $\begin{array}{ll}- & \text { Spot and forward } \\
\text { contracts } \\
\text { - } & \text { Strategic reserve stocks } \\
& \text { [Spe1] }\end{array}$ & $\mathrm{n} / \mathrm{a}$ & $\mathrm{n} / \mathrm{a}$ & $\mathrm{n} / \mathrm{a}$ & $\mathrm{n} / \mathrm{a}$ \\
\hline Hedging & 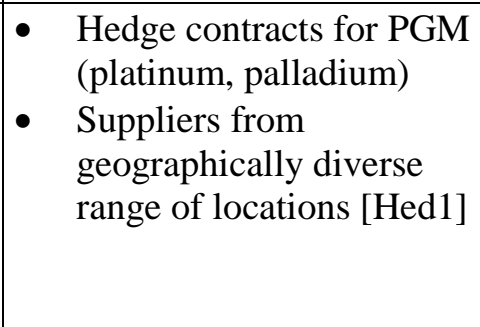 & 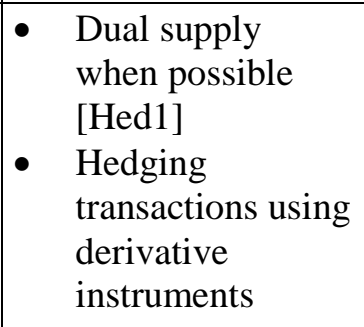 & $\mathrm{n} / \mathrm{a}$ & $\begin{array}{ll}- & \text { Regional sourcing } \\
\text { strategy } \\
\text { - } & \text { Multisource strategy } \\
& \text { allowing access to } \\
\text { additional inventories } \\
\text { [Hed1] }\end{array}$ & $\begin{array}{l}\text { Dual /multiple supply } \\
\text { (more than one supplier } \\
\text { for each component) } \\
\text { [Hed1] }\end{array}$ \\
\hline $\begin{array}{l}\text { Control/ share/ } \\
\text { transfer }\end{array}$ & 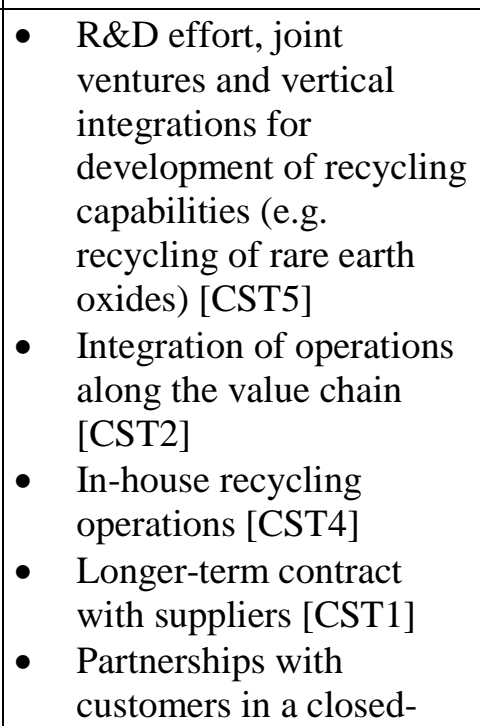 & $\begin{array}{ll}\text { - } & \text { Supply } \\
\text { agreements with } \\
\text { prices fixed over } \\
\text { the medium/long- } \\
\text { term [CST1] } \\
\text { - Link product } \\
\text { price increase } \\
\text { with material's } \\
\text { cost } \\
\text { Long-term } \\
\text { relationships with } \\
\text { suppliers }\end{array}$ & $\begin{array}{l}\text { Long-term } \\
\text { relationships } \\
\text { with suppliers }\end{array}$ & $\begin{array}{l}\text { - Concentrating the } \\
\text { supplier base for new } \\
\text { products and for } \\
\text { volume production } \\
\text { among a group mostly } \\
\text { made of "preferred" } \\
\text { suppliers who satisfy } \\
\text { our requirements. } \\
\text { - Work in partnership } \\
\text { with its suppliers }\end{array}$ & $\begin{array}{ll}\text { - } & \text { Alliance with suppliers } \\
\text { for manufacturing } \\
\text { strategic components. } \\
\text { - } & \text { Close, long-term } \\
& \text { relationships with } \\
\text { customers. } & \\
\text { - } & \text { Close, long-term } \\
\text { relationships with } \\
\text { suppliers. }\end{array}$ \\
\hline
\end{tabular}




\begin{tabular}{|c|c|c|c|c|c|}
\hline & \begin{tabular}{|l} 
loop business model \\
[CST6] \\
Negotiation of the \\
increase of the product \\
prices due to higher raw \\
material costs (rare earth \\
elements in 2011). \\
- Long-term \\
relations/retention with \\
customers and suppliers.
\end{tabular} & & & & \\
\hline Security & $\begin{array}{l}\text { Monitoring of the metals } \\
\text { prices [Sec2] }\end{array}$ & $\begin{array}{l}\text { Monitors the } \\
\text { trends of the } \\
\text { main } \\
\text { commodities } \\
\text { subject to the } \\
\text { greatest price } \\
\text { volatility [Sec2] }\end{array}$ & $\mathrm{n} / \mathrm{a}$ & $\mathrm{n} / \mathrm{a}$ & $\begin{array}{ll}\text { - } & \text { Increasing SC } \\
\text { transparency and } \\
\text { visibility (improving } \\
\text { traceability beyond our } \\
\text { direct - or Tier 1 - } \\
\text { suppliers) [Sec1] } \\
\text { Daily monitoring of the } \\
\text { quality and delivery } \\
\text { precision of purchased } \\
\text { items [Sec2] }\end{array}$ \\
\hline Avoidance & - $\quad$ Supplier audit & $\begin{array}{ll} & \text { Supplier } \\
& \text { selection, audit }\end{array}$ & $\begin{array}{ll} & \text { Supplier } \\
& \text { selection, audit }\end{array}$ & $\begin{array}{l}\text { - Risk assessment of the } \\
\text { supplier on annual } \\
\text { basis }\end{array}$ & - $\quad$ Supplier selection \\
\hline $\begin{array}{l}\text { Other } \\
\text { mitigation } \\
\text { strategies }\end{array}$ & $\begin{array}{ll}\text { - } & \text { Material efficiency: use } \\
\text { as less as possible [Oth5] } \\
\text { - } & \text { Substitution: using less } \\
\text { costly materials with } \\
\text { lower pricing volatility } \\
\text { [Oth9] } \\
\text { - } \\
\text { Dialogue with public } \\
\text { authorities on } \\
\text { development of standards } \\
\text { for recycling. } \\
\text { - }\end{array}$ & $\begin{array}{l}\text { Material policy to } \\
\text { avoid use of } \\
\text { CRM in the new } \\
\text { products [Oth5] } \\
\text { - Sustainable } \\
\text { procurement }\end{array}$ & $\begin{array}{ll} & \text { Sustainable } \\
& \text { procurement }\end{array}$ & $\begin{array}{ll}\text { - } & \text { Sustainable } \\
& \text { procurement }\end{array}$ & $\begin{array}{l}\text { Dialogue and } \\
\text { cooperation with } \\
\text { political leaders and } \\
\text { public authorities to } \\
\text { contribute opinions on } \\
\text { how legislation should } \\
\text { best be formulated. } \\
\text { - Sustainable procurement }\end{array}$ \\
\hline
\end{tabular}




\section{References}

Achzet, B., Helbig, C., 2013. How to evaluate raw material supply risks—an overview. Resour. Policy 38, $435-447$. doi:10.1016/j.resourpol.2013.06.003

Alonso, E., Gregory, J., Field, F., Kirchain, R., 2007. Material Availability and the Supply Chain : Risks, Effects, and Responses. Environ. Sci. Technol. 41, 6649-6656.

Bandaly, D., Shanker, L., Kahyaoglu, Y., Satir, A., 2013. Supply chain risk management-II: A review of operational, financial and integrated approaches. Risk Manag. 15, 1-31.

Bell, J.E., Autry, C.W., Mollenkopf, D. a., Thornton, L.M., 2012. A Natural Resource Scarcity Typology: Theoretical Foundations and Strategic Implications for Supply Chain Management. J. Bus. Logist. 33, 158-166. doi:10.1111/j.0000-0000.2012.01048.x

Bell, J.E., Mollenkopf, D. a., Stolze, H.J., 2013. Natural resource scarcity and the closed-loop supply chain: a resourceadvantage view. Int. J. Phys. Distrib. Logist. Manag. 43, 351-379. doi:10.1108/IJPDLM-03-2012-0092

British Geological Survey, 2012. Risk list 2012.

Buchert, M., Schüler, D., Bleher, D., 2009. Critical Metals For Future Sustainable Technologies And Their Recycling Potential.

Buijs, B., Espinoza, L.A.T., Sievers, H., 2012. Limits to the critical raw materials approach. Proc. Inst. Civ. Eng. Resour. Manag. 165 165, 201-208.

Buijs, B., Sievers, H., 2012. Critical Thinking about Critical Minerals : Assessing risks related to resource security.

Burrell, J., 2009. The Field Site as a Network: A Strategy for Locating Ethnographic Research. Field methods 21, 181199. doi:10.1177/1525822X08329699

Bustamante, M.L., Gaustad, G., 2014. Challenges in assessment of clean energy supply-chains based on byproduct minerals: A case study of tellurium use in thin film photovoltaics. Appl. Energy 1-18. doi:10.1016/j.apenergy.2014.01.065

Canbolat, Y.B., Gupta, G., Matera, S., Chelst, K., 2008. Analysing risk in sourcing design and manufacture of components and sub-systems to emerging markets. Int. J. Prod. Res. 46, 5145-5164. doi:10.1080/00207540701266807

Cavinato, J.L., 2004. Supply chain logistics risks. Int. J. Phys. Distrib. Logist. Manag. 34, 383-387.

Chopra, S., Sodhi, M.S., 2004. Managing Risk To Avoid Supply-Chain Breakdown. MIT Sloan Manag. Rev. 53-61.

Christopher, M., Peck, H., 2011. Building the Resilient Supply Chain. Int. J. Logist. Manag. 15, 1-14.

Cucchiella, F., Gastaldi, M., 2006. Risk management in supply chain: a real option approach. J. Manuf. Technol. Manag. 17, 700-720.

Day, M., Magnan, G.M., Moeller, M.M., 2010. Evaluating the bases of supplier segmentation: A review and taxonomy. Ind. Mark. Manag. 39, 625-639. doi:10.1016/j.indmarman.2009.06.001

Eisenhardt, K.M., 1989. Building Theories from Case. Acad. Manag. J. 14, 532-550.

Eisenhardt, K.M., Graebner, M.E., 2007. Theory Building from Cases: Opportunities and Challenges. Acad. Manag. J. 50, 25-32. doi:10.5465/AMJ.2007.24160888

Erdmann, L., Graedel, T.E., 2011. Criticality of non-fuel minerals: a review of major approaches and analyses. Environ. Sci. Technol. 45, 7620-30. doi:10.1021/es200563g

ETP SMR, 2013. European Technology Platform on Sustainable Mineral Resources. Strategic Research and Innovation Agenda.

European Commission, 2014a. Report on critical raw materials for the EU. Report of the Ad-Hoc Working Group on Defining Critical Raw Materials.

European Commission, 2014b. Report On Critical Raw Materials For The Eu. Critical Raw Materials Profiles.

European Commission, 2010. Critical raw materials for the EU. Report of the Ad-hoc Working Group on Defining Critical Raw Materials.

Faisal, M.N., 2009. Prioritization of Risks in Supply Chains, in: Wu, T., Blackhurst, J. (Eds.), Managing Supply Chain Risk and Vulnerability: Tools and Methods for Supply Chain Decision Makers. Springer- Verlag, London, pp. 41-66.

Fischl, M., Scherrer-Rathje, M., Friedli, T., 2014. Digging deeper into supply risk: a systematic literature review on price risks. Supply Chain Manag. An Int. J. 19, 480-503. doi:10.1108/SCM-12-2013-0474

Fizaine, F., 2013. Byproduct production of minor metals: Threat or opportunity for the development of clean technologies? The PV sector as an illustration. Resour. Policy 38, 373-383. doi:10.1016/j.resourpol.2013.05.002

Flint, D.J., Woodruff, R.B., Gardial, S.F., 2002. Customers ' Desired Value Change in a Business-to-Business Context Exploring the Phenomenon of. J. Mark. 66, 102-117. 
Flyvbjerg, B., 2006. Five Misunderstandings About Case-Study Research. Qual. Inq. 12, 219-245. doi:10.1177/1077800405284363

Giunipero, L.C., Eltantawy, R.A., 2004. Securing the upstream supply chain: a risk management approach. Int. J. Phys. Distrib. Logist. Manag. 34, 698-713.

Gleich, B., Achzet, B., Mayer, H., Rathgeber, A., 2013. An empirical approach to determine specific weights of driving factors for the price of commodities-A contribution to the measurement of the economic scarcity of minerals and metals. Resour. Policy 38, 350-362. doi:10.1016/j.resourpol.2013.03.011

Govindan, K., Jepsen, M.B., 2016. Supplier risk assessment based on trapezoidal intuitionistic fuzzy numbers and ELECTRE TRI-C: a case illustration involving service suppliers. J. Oper. Res. Soc. 67, 339-376. doi:10.1057/jors.2015.51

Govindan, K., Rajendran, S., Sarkis, J., Murugesan, P., 2013. Multi criteria decision making approaches for green supplier evaluation and selection: a literature review. J. Clean. Prod. 98, 66-83. doi:10.1016/j.jclepro.2013.06.046

Graedel, Barr, R., Chandler, C., Chase, T., Choi, J., Christoffersen, L., Friedlander, E., Henly, C., Jun, C., Nassar, N.T., Schechner, D., Warren, S., Yang, M.-Y., Zhu, C., 2012. Methodology of metal criticality determination. Environ. Sci. Technol. 46, 1063-70. doi:10.1021/es203534z

Graedel, Reck, B.K., 2015. Six Years of Criticality Assessments: What Have We Learned So Far? J. Ind. Ecol. 00, n/an/a. doi:10.1111/jiec.12305

Graedel, T.E., Gunn, G., Espinosa, L.T., 2014. Metal resources, use and criticality.

Green, N., 1999. Disrupting the Field. Virtual Reality Technilogies and "Multisited” Ethnographic Methods. Am. Behav. Sci. 43, 409-421.

Guba, E.G., 1981. ERIC/ECTJ Annual Review Paper: Criteria for Assessing the Trustworthiness of Naturalistic Inquiries. Educ. Commun. Technol. 29, 75-91.

Gunn, G., Bloodworth, A., 2012. Briefing: minerals security of supply: a geological perspective. Proc. ICE - Waste Resour. Manag. 165, 171-173.

Hallikas, J., Puumalainen, K., Vesterinen, T., Virolainen, V.-M., 2005. Risk-based classification of supplier relationships. J. Purch. Supply Manag. 11, 72-82. doi:10.1016/j.pursup.2005.10.005

Hatayama, H., Tahara, K., 2015. Evaluating the sufficiency of Japan's mineral resource entitlements for supply risk mitigation. Resour. Policy 44, 72-80.

Helbig, C., Wietschel, L., Thorenz, A., Tuma, A., 2016. How to evaluate raw material vulnerability - An overview. Resour. Policy 48, 13-24. doi:10.1016/j.resourpol.2016.02.003

Henckens, M.L.C.M., Driessen, P.P.J., Worrell, E., 2014. Metal scarcity and sustainability, analysing the necessity to reduce the extraction of scarce metals. Resour. Conserv. Recycl. 93, 1-8. doi:10.1016/j.resconrec.2014.09.012

Hirschman, E., 1986. Humanistic Inquiry in Marketing Research : Philosophy, Method, and Criteria. J. Mark. Res. 23, 237-249.

Ho, W., Xu, X., Dey, P.K., 2010. Multi-criteria decision making approaches for supplier evaluation and selection: A literature review. Eur. J. Oper. Res. 202, 16-24. doi:10.1016/j.ejor.2009.05.009

Ho, W., Zheng, T., Yildiz, H., Talluri, S., 2015. Supply chain risk management: a literature review. Int. J. Prod. Res. 53, 5031-5069. doi:10.1080/00207543.2015.1030467

Jüttner, U., Peck, H., Christopher, M., 2003. Supply Chain Risk Management : Outlining An Agenda For Future Research. Int. J. Logist. Res. Appl. 6, 197-210.

Krautkraemer, J.A., 2005. Economics of Natural Resource Scarcity: The State of the Debate. Resour. Futur.

Kull, T.J., Talluri, S., 2008. A Supply Risk Reduction Model Using Integrated Multicriteria Decision Making. IEEE Trans. Eng. Manag. 55, 409-419. doi:10.1109/TEM.2008.922627

Lin, Y., Zhou, L., 2011. The Impacts of Product Design Changes on Supply Chain Risk: A Case Study. Int. J. Phys. Distrib. Logist. Manag. 41, 162-186.

Macurová, P., Jurásková, K., 2013. Analysis of risks generated by suppliers during the period of economic fluctuation. Amfiteatru Econ. 15, 27-43.

Manuj, I., Mentzer, J.T., 2008. Global supply chain risk management strategies. Int. J. Phys. Distrib. Logist. Manag. 38, 192-223. doi:10.1108/09600030810866986

Matook, S., Lasch, R., Tamaschke, R., 2009. Supplier development with benchmarking as part of a comprehensive supplier risk management framework. Int. J. Oper. Prod. Manag. 29, 241-267.

Micheli, G.J.L., Cagno, E., Zorzini, M., 2008. Supply risk management vs supplier selection to manage the supply risk in the EPC supply chain. Manag. Res. News 31, 846-866. doi:10.1108/01409170810913042

Miles, H., Huberman, M., 1994. Qualitative Data Analysis: A Sourcebook. Sage Publications, Beverly HIlls, CA. 
Mollenkopf, D., Russo, I., Frankel, R., 2007. The returns management process in supply chain strategy. Int. J. Phys. Distrib. Logist. Manag. 37, 568-592.

Morley, N., Eatherley, D., 2008. Material Security. Ensuring resource availability for the UK economy.

Moss, R.L., Tzimas, E., Kara, H., Willis, P., Kooroshy, J., 2011. Critical Metals in Strategic Energy Technologies. Assessing Rare Metals as Supply-Chain Bottlenecks in Low-Carbon Energy Technologies. doi:10.2790/35716

Moss, R.L., Tzimas, E., Willis, P., Arendorf, J., Espinoza, L.T., Thompson, P., Chapman, A., Morley, N., Sims, E., Bryson, R., Pearson, J., Marscheider-Weidemann, F., Soulier, M., Lüllmann, A., Sartorius, C., Ostertag, K., 2013. Critical Metals in the Path towards the Decarbonisation of the EU Energy Sector. doi:10.2790/46338

Mroueh, U.-M., Bacher, J., Punkkinen, H., Brunot, A., Bolin, L., Stahl, S., Bette, K., Mattes, K., Joce, C., 2014. D4 . 4 CRM supply-chain analysis of Energy, ICT and electronics and Transport sectors.

Nadai, E., Maeder, C., 2005. Fuzzy Fields. Multi-Sited Ethnography in Sociological Research. Forum Qual. Soc. Res. 6.

Nieto, A., Guelly, K., Kleit, A., 2013. Addressing criticality for rare earth elements in petroleum refining: The key supply factors approach. Resour. Policy 38, 496-503. doi:10.1016/j.resourpol.2013.08.001

NRC, 2008. Minerals, Critical Minerals, and The U.S. Economy.

Panousi, S., Harper, E.M., Nuss, P., Eckelman, M.J., Hakimian, A., Graedel, T.E., 2015. Criticality of Seven Specialty Metals. J. Ind. Ecol. doi:10.1111/jiec.12295

Peck, D., Bakker, C., 2012. Eco-design opportunities for critical material supply risks, in: Electronics Goes Green 2012+, ECG 2012 - Joint International Conference and Exhibition, Proceedings.

Peck, D., Kandachar, P., Tempelman, E., 2015. Critical materials from a product design perspective. Mater. Des. 65, 147-159. doi:10.1016/j.matdes.2014.08.042

Poulton, M.M., Jagers, S.C., Linde, S., Van Zyl, D., Danielson, L.J., Matti, S., 2013. State of the World’s Nonfuel Mineral Resources: Supply, Demand, and Socio-Institutional Fundamentals. Annu. Rev. Environ. Resour. 38, 345-371. doi:10.1146/annurev-environ-022310-094734

Prior, T., Wäger, P. a, Stamp, A., Widmer, R., Giurco, D., 2013. Sustainable governance of scarce metals: the case of lithium. Sci. Total Environ. 461-462, 785-91. doi:10.1016/j.scitotenv.2013.05.042

Rao, S., Goldsby, T.J., 2011. Supply chain risks: A review and typology. Int. J. Logist. Manag. 20, 97-123.

Rosenau-Tornow, D., Buchholz, P., Riemann, A., Wagner, M., 2009. Assessing the long-term supply risks for mineral raw materials—a combined evaluation of past and future trends. Resour. Policy 34, 161-175. doi:10.1016/j.resourpol.2009.07.001

Saunders, M., Lewis, P., Thornhill, A., 2009. Research Methods for Business Students. Pearson Education Limited.

Slowinski, G., Latimer, D., Mehlman, S., 2013. Dealing with Shortages of Critical Materials. Res. Manag. 56, 18-24. doi:10.5437/08956308X5605139

Speirs, J., Gross, B., 2014. Materials availability for low-carbon technologies : An assessment of the evidence.

Strauss, A., Corbin, J., 1990. Basic of Qualitative Research: Grounded Theory Procedures atnd Technique. Sage Publications.

Stuart, I., McCutcheon, D., Handfield, R., McLachlin, R., Samson, D., 2002. Effective case research in operations management: a process perspective. J. Oper. Manag. 20, 419-433. doi:10.1016/S0272-6963(02)00022-0

Tang, C., 2006a. Robust strategies for mitigating supply chain disruptions. Int. J. Logist. 9, 33-45. doi:10.1080/13675560500405584

Tang, C., 2006b. Perspectives in supply chain risk management. Int. J. Prod. Econ. 103, 451-488.

Tang, C., Tomlin, B., 2008. The power of flexibility for mitigating supply chain risks. Int. J. Prod. Econ. 116, 12-27. doi:10.1016/j.ijpe.2008.07.008

Tang, O., Musa, S.N., 2011. Identifying risk issues and research advancements in supply chain risk management. Int. J. Prod. Econ. 133, 25-34. doi:10.1016/j.ijpe.2010.06.013

Tilton, J.E., 2003. On Borrowed Time? Assessing The Threat Of Mineral Depletion.

U.S. Department of Energy, 2011. Critical Materials Strategy.

U.S. Department of Energy, 2010. Critical Materials Strategy.

Wäger, P.A., Lang, D.J., Wittmer, D., Bleischwitz, R., Hagelüken, C., 2012. Towards a More Sustainable Use of Scarce Metals. A Review of Intervention Options along the Metals Life Cycle. GAIA 21, 300-309.

Wallendorf, M., Belk, R., 1989. Assessing Trustworthiness in Naturalistic Consumer Research, in: Hirschman, E. (Ed.), Interpretive Consumer Research. Provo, pp. 69-84.

Weiser, A., Lang, D.J., Schomerus, T., Stamp, A., 2015. Understanding the modes of use and availability of critical metals - An expert-based scenario analysis for the case of indium. J. Clean. Prod. 
doi:10.1016/j.jclepro.2015.01.079

Wu, T., Blackhurst, J., Chidambaram, V., 2006. A model for inbound supply risk analysis. Comput. Ind. 57, $350-365$. doi:10.1016/j.compind.2005.11.001

Yin, R.K., 2009. Case Study Research Design and Methods. Sage Publications.

Zsidisin, G.A., 2003. Managerial Perceptions of Supply Risk. J. Supply Chain Manag. 5, 14-26.

Zsidisin, G.A., Ellram, L.M., 2003. An Agency Theory Investigation of Supply Risk Management. J. Supply Chain Manag. 15-27.

Zsidisin, G.A., Ellram, L.M., Carter, J.R., Cavinato, J.L., 2004. An analysis of supply risk assessment techniques. Int. J. Phys. Distrib. Logist. Manag. 34, 397-413.

\section{References}

Achzet, B., Helbig, C., 2013. How to evaluate raw material supply risks—an overview. Resour. Policy 38, $435-447$. doi:10.1016/j.resourpol.2013.06.003

Alonso, E., Gregory, J., Field, F., Kirchain, R., 2007. Material Availability and the Supply Chain : Risks, Effects, and Responses. Environ. Sci. Technol. 41, 6649-6656.

Bandaly, D., Shanker, L., Kahyaoglu, Y., Satir, A., 2013. Supply chain risk management-II: A review of operational, financial and integrated approaches. Risk Manag. 15, 1-31.

Bell, J.E., Autry, C.W., Mollenkopf, D. a., Thornton, L.M., 2012. A Natural Resource Scarcity Typology: Theoretical Foundations and Strategic Implications for Supply Chain Management. J. Bus. Logist. 33, 158-166. doi:10.1111/j.0000-0000.2012.01048.x

Bell, J.E., Mollenkopf, D. a., Stolze, H.J., 2013. Natural resource scarcity and the closed-loop supply chain: a resourceadvantage view. Int. J. Phys. Distrib. Logist. Manag. 43, 351-379. doi:10.1108/IJPDLM-03-2012-0092

British Geological Survey, 2012. Risk list 2012.

Buchert, M., Schüler, D., Bleher, D., 2009. Critical Metals For Future Sustainable Technologies And Their Recycling Potential.

Buijs, B., Espinoza, L.A.T., Sievers, H., 2012. Limits to the critical raw materials approach. Proc. Inst. Civ. Eng. Resour. Manag. 165 165, 201-208.

Buijs, B., Sievers, H., 2012. Critical Thinking about Critical Minerals : Assessing risks related to resource security.

Burrell, J., 2009. The Field Site as a Network: A Strategy for Locating Ethnographic Research. Field Methods 21, 181199. doi:10.1177/1525822X08329699

Bustamante, M.L., Gaustad, G., 2014. Challenges in assessment of clean energy supply-chains based on byproduct minerals: A case study of tellurium use in thin film photovoltaics. Appl. Energy 1-18. doi:10.1016/j.apenergy.2014.01.065

Canbolat, Y.B., Gupta, G., Matera, S., Chelst, K., 2008. Analysing risk in sourcing design and manufacture of components and sub-systems to emerging markets. Int. J. Prod. Res. 46, 5145-5164. doi:10.1080/00207540701266807

Cavinato, J.L., 2004. Supply chain logistics risks. Int. J. Phys. Distrib. Logist. Manag. 34, 383-387.

Chopra, S., Sodhi, M.S., 2004. Managing Risk To Avoid Supply-Chain Breakdown. MIT Sloan Manag. Rev. 53-61.

Christopher, M., Peck, H., 2011. Building the Resilient Supply Chain. Int. J. Logist. Manag. 15, 1-14.

Cucchiella, F., Gastaldi, M., 2006. Risk management in supply chain: a real option approach. J. Manuf. Technol. Manag. 17, 700-720.

Day, M., Magnan, G.M., Moeller, M.M., 2010. Evaluating the bases of supplier segmentation: A review and taxonomy. Ind. Mark. Manag. 39, 625-639. doi:10.1016/j.indmarman.2009.06.001

Eisenhardt, K.M., 1989. Building Theories from Case. Acad. Manag. J. 14, 532-550.

Eisenhardt, K.M., Graebner, M.E., 2007. Theory Building from Cases: Opportunities and Challenges. Acad. Manag. J. 50, 25-32. doi:10.5465/AMJ.2007.24160888 
Erdmann, L., Graedel, T.E., 2011. Criticality of non-fuel minerals: A review of major approaches and analyses. Environ. Sci. Technol. 45, 7620-30. doi:10.1021/es200563g

ETP SMR, 2013. European Technology Platform on Sustainable Mineral Resources. Strategic Research and Innovation Agenda.

European Commission, 2014a. Report on critical raw materials for the EU. Report of the Ad-Hoc Working Group on Defining Critical Raw Materials.

European Commission, 2014b. Report On Critical Raw Materials For The EU. Critical Raw Materials Profiles.

European Commission, 2010. Critical raw materials for the EU. Report of the Ad-hoc Working Group on Defining Critical Raw Materials.

Faisal, M.N., 2009. Prioritization of Risks in Supply Chains, in: Wu, T., Blackhurst, J. (Eds.), Managing Supply Chain Risk and Vulnerability: Tools and Methods for Supply Chain Decision Makers. Springer- Verlag, London, pp. 4166.

Fischl, M., Scherrer-Rathje, M., Friedli, T., 2014. Digging deeper into supply risk: a systematic literature review on price risks. Supply Chain Manag. An Int. J. 19, 480-503. doi:10.1108/SCM-12-2013-0474

Fizaine, F., 2013. Byproduct production of minor metals: Threat or opportunity for the development of clean technologies? The PV sector as an illustration. Resour. Policy 38, 373-383. doi:10.1016/j.resourpol.2013.05.002

Flint, D.J., Woodruff, R.B., Gardial, S.F., 2002. Customers ' Desired Value Change in a Business-to-Business Context Exploring the Phenomenon of. J. Mark. 66, 102-117.

Flyvbjerg, B., 2006. Five Misunderstandings About Case-Study Research. Qual. Inq. 12, $219-245$. doi:10.1177/1077800405284363

Giunipero, L.C., Eltantawy, R.A., 2004. Securing the upstream supply chain: a risk management approach. Int. J. Phys. Distrib. Logist. Manag. 34, 698-713.

Gleich, B., Achzet, B., Mayer, H., Rathgeber, A., 2013. An empirical approach to determine specific weights of driving factors for the price of commodities-A contribution to the measurement of the economic scarcity of minerals and metals. Resour. Policy 38, 350-362. doi:10.1016/j.resourpol.2013.03.011

Govindan, K., Jepsen, M.B., 2016. Supplier risk assessment based on trapezoidal intuitionistic fuzzy numbers and ELECTRE TRI-C: a case illustration involving service suppliers. J. Oper. Res. Soc. 67, 339-376. doi:10.1057/jors.2015.51

Govindan, K., Rajendran, S., Sarkis, J., Murugesan, P., 2013. Multi criteria decision making approaches for green supplier evaluation and selection: a literature review. J. Clean. Prod. 98, 66-83. doi:10.1016/j.jclepro.2013.06.046

Graedel, Barr, R., Chandler, C., Chase, T., Choi, J., Christoffersen, L., Friedlander, E., Henly, C., Jun, C., Nassar, N.T., Schechner, D., Warren, S., Yang, M.-Y., Zhu, C., 2012. Methodology of metal criticality determination. Environ. Sci. Technol. 46, 1063-70. doi:10.1021/es203534z

Graedel, Reck, B.K., 2015. Six Years of Criticality Assessments: What Have We Learned So Far? J. Ind. Ecol. 00, n/an/a. doi:10.1111/jiec.12305

Graedel, T.E., Gunn, G., Espinosa, L.T., 2014. Metal resources, use and criticality.

Green, N., 1999. Disrupting the Field. Virtual Reality Technologies and "Multisited” Ethnographic Methods. Am. Behav. Sci. 43, 409-421.

Guba, E.G. 1981. ERIC/ECTJ Annual Review Paper: Criteria for Assessing the Trustworthiness of Naturalistic Inquiries. Educ. Commun. Technol. 29, 75-91.

Gunn, G., Bloodworth, A., 2012. Briefing: minerals security of supply: a geological perspective. Proc. ICE - Waste Resour. Manag. 165, 171-173.

Hallikas, J., Puumalainen, K., Vesterinen, T., Virolainen, V.-M., 2005. Risk-based classification of supplier relationships. J. Purch. Supply Manag. 11, 72-82. doi:10.1016/j.pursup.2005.10.005

Hatayama, H., Tahara, K., 2015. Evaluating the sufficiency of Japan's mineral resource entitlements for supply risk mitigation. Resour. Policy 44, 72-80. 
Helbig, C., Wietschel, L., Thorenz, A., Tuma, A., 2016. How to evaluate raw material vulnerability - An overview. Resour. Policy 48, 13-24. doi:10.1016/j.resourpol.2016.02.003

Henckens, M.L.C.M., Driessen, P.P.J., Worrell, E., 2014. Metal scarcity and sustainability, analysing the necessity to reduce the extraction of scarce metals. Resour. Conserv. Recycl. 93, 1-8. doi:10.1016/j.resconrec.2014.09.012

Hirschman, E., 1986. Humanistic Inquiry in Marketing Research : Philosophy, Method, and Criteria. J. Mark. Res. 23, 237-249.

Ho, W., Xu, X., Dey, P.K., 2010. Multi-criteria decision making approaches for supplier evaluation and selection: A literature review. Eur. J. Oper. Res. 202, 16-24. doi:10.1016/j.ejor.2009.05.009

Ho, W., Zheng, T., Yildiz, H., Talluri, S., 2015. Supply chain risk management: a literature review. Int. J. Prod. Res. 53, 5031-5069. doi:10.1080/00207543.2015.1030467

Jüttner, U., Peck, H., Christopher, M., 2003. Supply Chain Risk Management: Outlining An Agenda For Future Research. Int. J. Logist. Res. Appl. 6, 197-210.

Krautkraemer, J.A., 2005. Economics of Natural Resource Scarcity: The State of the Debate. Resour. Futur.

Kull, T.J., Talluri, S., 2008. A Supply Risk Reduction Model Using Integrated Multicriteria Decision Making. IEEE Trans. Eng. Manag. 55, 409-419. doi:10.1109/TEM.2008.922627

Lin, Y., Zhou, L., 2011. The Impacts of Product Design Changes on Supply Chain Risk: A Case Study. Int. J. Phys. Distrib. Logist. Manag. 41, 162-186.

Macurová, P., Jurásková, K., 2013. Analysis of risks generated by suppliers during the period of economic fluctuation. Amfiteatru Econ. 15, 27-43.

Manuj, I., Mentzer, J.T., 2008. Global supply chain risk management strategies. Int. J. Phys. Distrib. Logist. Manag. 38, 192-223. doi:10.1108/09600030810866986

Matook, S., Lasch, R., Tamaschke, R., 2009. Supplier development with benchmarking as part of a comprehensive supplier risk management framework. Int. J. Oper. Prod. Manag. 29, 241-267.

Micheli, G.J.L., Cagno, E., Zorzini, M., 2008. Supply risk management vs supplier selection to manage the supply risk in the EPC supply chain. Manag. Res. News 31, 846-866. doi:10.1108/01409170810913042

Miles, H., Huberman, M., 1994. Qualitative Data Analysis: A Sourcebook. Sage Publications, Beverly Hills, CA.

Mollenkopf, D., Russo, I., Frankel, R., 2007. The returns management process in supply chain strategy. Int. J. Phys. Distrib. Logist. Manag. 37, 568-592.

Morley, N., Eatherley, D., 2008. Material Security. Ensuring resource availability for the UK economy.

Moss, R.L., Tzimas, E., Kara, H., Willis, P., Kooroshy, J., 2011. Critical Metals in Strategic Energy Technologies. Assessing Rare Metals as Supply-Chain Bottlenecks in Low-Carbon Energy Technologies. doi:10.2790/35716

Moss, R.L., Tzimas, E., Willis, P., Arendorf, J., Espinoza, L.T., Thompson, P., Chapman, A., Morley, N., Sims, E., Bryson, R., Pearson, J., Marscheider-Weidemann, F., Soulier, M., Lüllmann, A., Sartorius, C., Ostertag, K., 2013. Critical Metals in the Path towards the Decarbonisation of the EU Energy Sector. doi:10.2790/46338

Mroueh, U.-M., Bacher, J., Punkkinen, H., Brunot, A., Bolin, L., Stahl, S., Bette, K., Mattes, K., Joce, C., 2014. D4 . 4 CRM supply-chain analysis of Energy, ICT and electronics and transport sectors.

Nadai, E., Maeder, C., 2005. Fuzzy Fields. Multi-Sited Ethnography in Sociological Research. Forum Qual. Soc. Res. 6.

Nieto, A., Guelly, K., Kleit, A., 2013. Addressing criticality for rare earth elements in petroleum refining: The key supply factors approach. Resour. Policy 38, 496-503. doi:10.1016/j.resourpol.2013.08.001

NRC, 2008. Minerals, Critical Minerals, and The U.S. Economy.

Panousi, S., Harper, E.M., Nuss, P., Eckelman, M.J., Hakimian, A., Graedel, T.E., 2015. Criticality of Seven Specialty Metals. J. Ind. Ecol. doi:10.1111/jiec.12295

Peck, D., Bakker, C., 2012. Eco-design opportunities for critical material supply risks, in: Electronics Goes Green 2012+, ECG 2012 - Joint International Conference and Exhibition, Proceedings.

Peck, D., Kandachar, P., Tempelman, E., 2015. Critical materials from a product design perspective. Mater. Des. 65, 147-159. doi:10.1016/j.matdes.2014.08.042 
Poulton, M.M., Jagers, S.C., Linde, S., Van Zyl, D., Danielson, L.J., Matti, S., 2013. State of the World's Nonfuel Mineral Resources: Supply, Demand, and Socio-Institutional Fundamentals. Annu. Rev. Environ. Resour. 38, 345-371. doi:10.1146/annurev-environ-022310-094734

Prior, T., Wäger, P. a, Stamp, A., Widmer, R., Giurco, D., 2013. Sustainable governance of scarce metals: the case of lithium. Sci. Total Environ. 461-462, 785-91. doi:10.1016/j.scitotenv.2013.05.042

Rao, S., Goldsby, T.J., 2011. Supply chain risks: A review and typology. Int. J. Logist. Manag. 20, 97-123.

Rosenau-Tornow, D., Buchholz, P., Riemann, A., Wagner, M., 2009. Assessing the long-term supply risks for mineral raw materials-a combined evaluation of past and future trends. Resour. Policy 34, 161-175. doi:10.1016/j.resourpol.2009.07.001

Saunders, M., Lewis, P., Thornhill, A., 2009. Research Methods for Business Students. Pearson Education Limited.

Slowinski, G., Latimer, D., Mehlman, S., 2013. Dealing with Shortages of Critical Materials. Res. Manag. 56, $18-24$. doi:10.5437/08956308X5605139

Speirs, J., Gross, B., 2014. Materials availability for low-carbon technologies : An assessment of the evidence.

Strauss, A., Corbin, J., 1990. Basic of Qualitative Research: Grounded Theory Procedures and Technique. Sage Publications.

Stuart, I., McCutcheon, D., Handfield, R., McLachlin, R., Samson, D., 2002. Effective case research in operations management: A process perspective. J. Oper. Manag. 20, 419-433. doi:10.1016/S0272-6963(02)00022-0

Tang, C., 2006a. Robust strategies for mitigating supply chain disruptions. Int. J. Logist. 9, 33-45. doi:10.1080/13675560500405584

Tang, C., 2006b. Perspectives in supply chain risk management. Int. J. Prod. Econ. 103, 451-488.

Tang, C., Tomlin, B., 2008. The power of flexibility for mitigating supply chain risks. Int. J. Prod. Econ. 116, 12-27. doi:10.1016/j.ijpe.2008.07.008

Tang, O., Musa, S.N., 2011. Identifying risk issues and research advancements in supply chain risk management. Int. J. Prod. Econ. 133, 25-34. doi:10.1016/j.ijpe.2010.06.013

Tilton, J.E., 2003. On Borrowed Time? Assessing The Threat Of Mineral Depletion.

U.S. Department of Energy, 2011. Critical Materials Strategy.

U.S. Department of Energy, 2010. Critical Materials Strategy.

Wäger, P.A., Lang, D.J., Wittmer, D., Bleischwitz, R., Hagelüken, C., 2012. Towards a More Sustainable Use of Scarce Metals. A Review of Intervention Options along the Metals Life Cycle. GAIA 21, 300-309.

Wallendorf, M., Belk, R., 1989. Assessing Trustworthiness in Naturalistic Consumer Research, in: Hirschman, E. (Ed.), Interpretive Consumer Research. Provo, pp. 69-84.

Weiser, A., Lang, D.J., Schomerus, T., Stamp, A., 2015. Understanding the modes of use and availability of critical metals - An expert-based scenario analysis for the case of indium. J. Clean. Prod. doi:10.1016/j.jclepro.2015.01.079

Wu, T., Blackhurst, J., Chidambaram, V., 2006. A model for inbound supply risk analysis. Comput. Ind. 57, 350-365. doi:10.1016/j.compind.2005.11.001

Yin, R.K., 2009. Case Study Research Design and Methods. Sage Publications.

Zsidisin, G.A., 2003. Managerial Perceptions of Supply Risk. J. Supply Chain Manag. 5, 14-26.

Zsidisin, G.A., Ellram, L.M., 2003. An Agency Theory Investigation of Supply Risk Management. J. Supply Chain Manag. 15-27.

Zsidisin, G.A., Ellram, L.M., Carter, J.R., Cavinato, J.L., 2004. An analysis of supply risk assessment techniques. Int. J. Phys. Distrib. Logist. Manag. 34, 397-413. 